\title{
SUITS IN EQUITY BY MINORITY STOCKHOLDERS AS A MEANS OF CORPORATE CONTROL
}

\section{Chester Rohritch $\dagger$}

There is no need to enter upon any philosophical speculation as to the nature of a corporation ${ }^{1}$ to recognize, as equity does, that at all times beneath the cloak of the corporate entity there exist the stockholders. ${ }^{2}$ Generally what is good for them is good for their corporation, and conversely what is good for the corporation is good for its stockholders. But what is good, in business as in morals, is not always beyond debate. Differences of opinion as to the proper course of corporate conduct are therefore inevitable. Unanimity is also not infrequently prevented by the fact that each stockholder gives weight to factors that interest him alone and not necessarily solely in his capacity of stockholder in the particular corporation. Indeed, in view of the network of corporations that now pervades life a person is not infrequently in direct competition with corporations whose stock he owns. These conflicts of opinion and interest are in most cases settled within the corporation, ${ }^{3}$ but the resort to courts by dissatisfied minorities is an increasingly common practice.

\section{Equitable Intervention ${ }^{4}$}

In approaching the problem of when and to what extent courts of equity will interfere in the internal affairs of a corporation, it seems expedient first to note the "general principles", so that we may thereafter better appreciate the different lines of thought available to a chancellor faced with the facts of a particular controversy.

†LL. B., New Fork University, I92I; member of New York Bar; contributor to numerous legal periodicals; at present engaged in the preparation of a series of articles on various phases of corporate control. 643.

${ }^{1}$ See Radin, The Endless Problem of Corporate Personality (1932) 32 CoL. L. Rev.

2 "But who is the Company? A mere entity created by law, without body or soul, endowed with capacity to acquire, hold, and dispose of property, in trust for the use and benefit of the natural persons of whom it is composed in proportion of their several interests therein. But its property belongs in equity to the corporators, . . . Hence, courts of equity look beyond the artificial creature in whom is the legal title to the real persons whom it represents." Meeker v. Winthrop Iron Co., I7 Fed. 48, 50 (C. C. W. D. Mich. I883). See Revlock Supply Co. v. Troxell, 28I Pa. 424, I26 At1. 744 (I924); WormSER, DisRDGARD of tHe Corporate Fiction (I929); Warren, Corporate Advantages Without InCORPORATION (I929).

${ }^{3}$ See Rohrlich, Corporate Voting: Majority Control, shortly to be published in ST. JoHn's L. REV.

- Intervention may be negative as well as positive. A decree in defendant's favor does not necessarily establish that the court did not intervene. 
The starting dictum is that "a court of equity has no visitorial powers over corporations, except such as may be expressly conferred on it by statute." 5 The first breach made in this absolute rule was that equity would at the instance of stockholders give redress against ultra vires acts. ${ }^{6}$ The proposition that equity would interfere in cases of ultra vires acts had its converse that "so long as the corporation keeps within the limits of its charter" equity would not interfere. ${ }^{7}$

The simple test of power did not long suffice. The chancellor was soon faced with charges of abuse of power. He thereupon imposed upon those who had the power the obligation not to act fraudulently or in bad faith. The opinion in Ervin v. Oregon Railway \& Navigation Company ${ }^{8}$ indicates the many threads that are intertwined in the present-day concept of the power of equity to intervene in intra-corporate controversies.

"Plainly, the defendants have assumed to exercise a power belonging to the majority, in order to secure personal profit for themselves, without regard to the interests of the minority. They repudiate the suggestion of fraud, and plant themselves upon their rights as a majority to control the corporate interests according to their discretion. They err if they suppose that a court of equity will tolerate a discretion which does not consult the interests of the minority. It cannot be denied that minority stockholders are bound hand and foot to the majority in all matters of legitimate administration of the corporate affairs; and the courts are powerless to redress many forms of oppression practiced upon the minority under the guise of legal sanction, which fall short of actual fraud. This is a consequence of the implied contract of association by which it is agreed, in advance, that a majority shall bind the whole body as to all transactions within the scope of the corporate powers. . . . When a number of stockholders combine to constitute themselves a majority in order to control the corporation as they see fit, they become for all practical purposes the corporation itself, and assume the trust relation occupied by the corporation towards its stockholders. . . . The corporation itself holds its property as a trust fund for the stockholders who have a joint interest in all its property and effects, and the relation between it and its several members is, for all practical purposes, that of trustee and cestui que trust." 9

${ }^{8}$ Latimer v. Eddy, 46 Barb. 6r, 67 (N. Y. I864). In this article we shall in the main confine ourselves to non-statutory powers of equity. Some attempt has been made to fix the right of minority stockholders to resort to equity by statute, e. g., G.A. CODE ANN. (Michie, 1926) \$2224.

- For collections of cases see 3 Cook; Corporations (8thi ed. 1923) $\$ 669$; I3 Fletcher, Cyclopedia of Corporations (Perm. ed. I932) \$\$ 5823-5828; 4 Thompson, Corporations (3d ed. 1927) \$2906-2908. As the result of increasingly liberal general corporation statutes and the use of the broadest possible terminology in certificates of incorporation, the problem of ultra vires is now of slight importance. See (I932) 45 HARV. L. REV. I393. It will not be treated further in this article. The problems with which we will be concerned are those arising out of the exercise of powers which concededly exist.

'Fountain Ferry Turnpike Road Co. v. Jewell, 8 B. Mon. I40, I45 (Ky. I848).

${ }^{8} 27$ Fed. 625 (C. C. S. D. N. Y. I886).

${ }^{\circ} I d$. at $630-63 \mathrm{I}$. 
We have here the three major concepts which a court of equity must now reconcile and apply to the facts before it: (I) the majority are supreme in the management of the purely business affairs of the corporation; (2) the majority may not commit frauds; and (3) the minority are the beneficiaries of a trust.

Madsen v. Burns Bros. ${ }^{10}$ affords a good illustration of the application of the first of these concepts. In I930, Burns Bros. sustained a loss of almost $\$ \mathrm{I}, 400,000$ and the owners of a small minority of its stock thereupon petitioned for the appointment of a receiver to the end that the corporation cease doing business. ${ }^{11}$ The court dismissed the complaint, saying:

"Whether the business of a corporation should be operated at a loss during a business depression, or close down at a smaller loss, is a purely business and economic problem to be determined by the directors, and not by the court." 12

\section{In a leading case ${ }^{13}$ the same view was expressed as follows:}

"It is not, however, every question of mere administration or policy in which there is a difference of opinion among the shareholders that enables the minority to claim that the action of the majority is oppressive, and which justifies the minority in coming to a court of equity to obtain relief. Generally, the rule must be that in such cases the will of the majority shall govern. The court would not be justified in interfering even in doubtful cases, where the action of the majority might be susceptible of different constructions. . . . Otherwise the court might be called upon to balance probabilities of profitable results to arise from the carrying out of the one or the other of the different plans proposed by or on behalf of different shareholders in a corporation and to decree the adoption of that line of policy which seemed to

${ }^{10}$ I08 N. J. Eq. 275, I55 At1. 28 (I93I).

11 The petition was filed under Section 65 of the New Jersey Corporation Act which authorizes any stockholders owning at least 10\% of the capital stock of a corporation to petition the court of chancery, which is given the power to enjoin the transaction of business and appoint a receiver if it is satisfied that the corporation's "business has been and is being conducted at a great loss and greatly prejudicial to the interests of its creditors or stockholders, so that its business cannot be conducted with safety to the public and advantage to the stockholders." Although the proceedings were statutory the remarks of the chancellor are couched in general equity phraseology.

${ }^{2}$ Supra note 10, at 279 . The case also involved the propriety of a debt-funding operation. The court held that this too was a "business and economic" problem upon which "the judgment of the majority of the board of directors must prevail in the absence of fraud, ultra vires, illegality, or a showing of mala fides or abuse of power tantamount to fraud." The court found that the corporation was not insolvent and that the loss was not due to mismanagement. But it has been said that "losses resulting from ignorant or even foolish mismanagement cannot be recovered". Smith v. Chase \& Baker Piano Mfg. Co., I97 Fed. $466,47 \mathrm{I}$ (E. D. Mich. I9I2). "Mere errors of judgment are not sufficient as grounds for equity interference". Leslie v. Lorillard, Iro N. Y. 5I9, 532, I8 N. E. 363, 365 (I888). For other cases where courts refused to interfere on the ground that the questions involved were purely of business policy see Theis v. Spokane Falls Gas Light Co., 49 Wash. 477, 95 Pac. I074 (I908) (expansion of corporation); Ellerman v. Chicago Junction Rys. Co., 49 N. J. Eq. 2I7, 23 Atl. 287 (I89I) (acquisition of competing business); Matter of Hinds, Noble \& Eldredge, 172 App. Div. I40, I58 N. Y. Supp. 249 (I9I6), aff'd 2 I8 N. Y. 7I5, II3 N. E. 1058 (I9I6) (change of name); Carter v. Spring Perch Co., II3 Conn. 636, I55 Atl. 832 (I931) (change of place of business and change in quality and price of product).

${ }^{13}$ Gamble v. Queens County Water Co., I23 N. Y. 9I, 25 N. E. 201 (I890): 
it to promise the best results, or at least to enjoin the carrying out of the opposite policy. This is no business of any court to follow." 14

The practical justification for this yielding to the majority is found in the need for efficiency and expedition. The corporation must function. Better an erroneous decision than an interminable stalemate. The theoretical justification is found in the terms of the contract stated to exist between the stockholders and the corporation as embodied in the charter, by-laws, statutes and common-law. ${ }^{15}$

Justification for the intervention of equity to prevent fraud ${ }^{16}$ is obvious. ${ }^{17}$ In Flynn v. Brooklyn City Railroad Company, the New York Court of Appeals said:

"To these general rules [that 'courts have nothing to do with the internal management of business corporations'], however, there are some exceptions, and the most important is that founded on fraud. While courts cannot compel directors or stockholders proceeding by the vote of a majority, to act wisely, they can compel them to act honestly, or undo their work if they act otherwise. Where a majority of the directors, or stockholders, or both, acting in bad faith, carry into effect a scheme which, even if lawful upon its face, is intended to circumvent the minority stockholders and defraud them out of their legal rights, the courts interfere and remedy the wrong." 18

The application of the doctrines of trusts to corporations has undergone many changes, and the end is not yet. If a trust relationship is found,

${ }^{14} I d$. at 99.

${ }^{2}$ See Jones v. Missouri-Edison Electric Co., 144 Fed. 765,770 (C. C. A. 8th, 1906); Colby v. Equitable Trust Co., I24 App. Div. 262, 266, I08 N. Y. Supp. 978, 98I (I908), aff'd I92 N. Y. 535, 84 N. E. IIII (I908); CoOK, CoRporatTons (Sth ed. I923) $\$ \$ 493,669$. The propriety of treating the mere purchase of a stock certificate as the equivalent of intelligent consent to all the terms of the "contract" is outside the scope of this article. See infra notes 202,203 , and text.

${ }^{20}$ Equity "has ever refused to define [fraud] lest the craft of man evade the definition." Shonfeld v. Shonfeld, 260 N. Y. 477,479 (I933).

${ }_{17}$ Most of the cases involving charges of fraud involve interested directors or holding companies. These are among the major problems in corporation law today, but the limitations of space prevent any special treatment of them in this article. Sed SPELLMAAN, CoRPORATE DIRECTORS (193I) c. ix; Mound, Suits Alleging Mismanagement of Subsidiaries by Holding Companies or Parent Companies, published as an appendix to BonBRIGHT AND Means, The Holding Company (I932); Berle, Studies in the Law of Corporate Finance (1928) c. viii; Bowman, The Validity of Contracts Between Corporations Having Common Directors (I906) 4 MICE. L. REv. 577; James, Interested Directors in Corporate Transactions (I93I) 6 IND. L. J. 4 I3 ; Note (I933) 8I U. of PA. L. Rev. 598.

${ }^{13}$ I58 N. Y. 493, 507-8, 53 N. E. 520, 524 (I899). The complaint in this case was dismissed because it failed sufficiently to allege a prior demand on the corporation to sue. In an earlier case, Barr v. N. Y. L. E. \& W. R. R. Co., 96 N. Y. 444 (I884), the same court sustained a complaint by a minority stockholder of a lessor corporation against its lessee to enforce payment of rent under the lease, which alleged that the lessee controlled the lessor. See also Steinfeld v. Copper State Min. Co., 37 Ariz. I5I, 163, 290 Pac. I55, I60 (I930), where it is suggested that the majority owe to the minority the duty not only to exercise good faith but also to exercise "care and diligence." There is a conflict in the decisions as to the degree of care to which directors are held. See 2 Thompson, Corporations (3d ed. I927) c. 50; Briggs v. Spaulding, I4I U. S. I32, II Sup. Ct. 924 (I8gI); Kavanaugh v. Commonwealth Trust Co., 223 N. Y. I03, Irg N. E. 237 (I9I8); People v. Mancuso, 255 N. Y. 463 , I75 N. E. 177 (I93I). 
the jurisdiction of equity follows almost inevitably and the "breach of trust of one who occupies a fiduciary relation while in the exercise of a lawful power is as fatal in equity to the resultant act or contract as the absence of the power." 19 That the corporation itself is a trustee for the stockholders is well settled. ${ }^{20}$ Nor is there any doubt that directors are "trustees" for the corporation. ${ }^{21}$ Although it is sometimes stated that they are trustees "for the stockholders", ${ }^{22}$ if this be taken to mean the several stockholders individually, the statement is not entirely correct. ${ }^{23}$ However, the problems to be presented in this article involve primarily the relationship between the majority and the minority. Is it one of trust? At one extreme is complete denial of the notion that stockholders are trustees for each other. $^{24}$ This view has been vigorously asserted.

"Whenever any action of either directors or stockholders is relied on in a suit by a minority stockholder for the purpose of invoking the interposition of a court of equity, if the act complained of be neither ultra vires, fraudulent, nor illegal, the court will refuse its intervention because powerless to grant it, and will leave all such matters to be disposed of by the majority of the stockholders in such manner as their interests may dictate, and their action will be binding on all, whether approved of by the minority or not. . . . The fact that the same persons hold the majority of the stock in both companies does not of itself enlarge the court's jurisdiction, the act complained of furnishes the test of jurisdiction, and it must be ultra vires, fraudulent or illegal; nothing short of this will suffice. . . . They [stockholders] are not trustees or quasi trustees for each other. . . . And if the proposed lease be not ultra vires or unlawful or fraudulent, no court, at the instance of a minority stockholder, or at the instance of anyone else, has the power or the right to restrain the majority from dealing with the property as they may deem most advantageous to their own interests. Any other doctrine would put it in the power of a single stockholder, owning but one share out of many hundreds, to transfer the entire management of a corporation to a court of equity and would effectually de-

${ }^{10}$ Jones v. Missouri-Edison Electric Co., supra note I5, at $77 \mathbf{r}$.

${ }^{20}$ Hyams v. Old Dominion Co., $x_{3} 3$ Me. 294, 306, 93 At1. 747, 752 (1915). Generally, when the word "trustee" is used in corporate litigation, it is used merely as a convenient abbreviation for describing a somewhat uncertain type of fiduciary, and not in its strictly technical sense.

${ }^{21}$ See 3 Fletcher, op. cit. supra note $6, \S 838$. Because directors are not technical trustees even for the corporation, Shaw v. Davis, 78 Md. 308, 318, 28 At1. 619, 622 (I894), they are permitted to profit personally in certain situations. See Stanton v. Schenck, I4O Misc. 62I, 25I N. Y. Supp. 22I (I93I).

Jackson v. Ludeling, 2I Wall. 616 (U. S. I874).

a See Wilgus, Purchase of Shares of Corporation by a Director from a Shareholder ( I9ro) 8 Mick. L. REv. 267; Laylin, The Duty of a Director Purchasing Shares of Stock (IgI8) 27 Y AIE I. J. 73I ; Smith, Purchase of Shares of Corporation. by a Director from a Shareholder (I92I) 19 Mich. L. Rev. 698; Walker, The Duty of Disclosure by a Director Purchasing Stock from His Stockholder (Ig23) 32 YALE L. J. 637; Note (I925) Io CORN. L. Q. 509; Mariash, Fiduciary Relationship Between Director and Stockholder, N. Y. L. J., Feb. 20, I933, at 1022.

${ }^{24}$ Shaw v. Davis, supra note 21 ; Niles v. N. Y. C. \& D. R. R. Co., 69 App. Div. I44, 74 N. Y. Supp. 6ry (I902), aff'd I76 N. Y. II9, 68 N. E. I42 (I903); Gamble v. Queens C. W. Co., supra note 13 . 
stroy the right of the owners of the property lawfully to control it themselves. It would make a court of equity practically the guardian, so to speak, of such a corporation and would substitute the Chancellor's belief as to what contracts a corporation ought, as a matter of expediency, or policy, or business venture to make, instead of allowing such questions to be settled by the persons beneficially interested in the property." 25

At the other extreme is the suggestion that "all powers granted to a corporation or to the management of a corporation, or to any group within the corporation . . . are necessarily and at all times exercisable only for the ratable benefit of all shareholders as their interest appears [and] that, in consequence, the use of the power is strbject to equitable limitation when the power has been exercised to the detriment of such interest, however absolute the grant of power may be in terms, and however correct the technical exercise of it may have been." 26 These attempts to subordinate corporation law into a mere phase of the law of trusts have, of course, not gone unchallenged. One criticizes the trustee theory as being in derogation of the contract nature of corporate enterprises. ${ }^{27}$ Another on the grounds of corporate efficiency and the lack of sufficient business knowledge and experience on the part of courts. ${ }^{28}$

The courts have chosen a middle-course, holding that majority stockholders who do in fact control occupy a fiduciary relation to the minority, ${ }^{29}$ but that such trust relationship does not arise from the mere power to control by virtue of majority stock ownership. ${ }^{30}$ The distinction has been well put in Robotham v. Prudential Ins. Co.:

$\approx$ Shaw v. Davis, supra note $2 \mathrm{I}$, at 316, 318, 328, 28 Atl. at 621, 622, 625 .

${ }^{20}$ Berle, Corporate Powers as Pczers in Trust (I93I) 44 HARv. L. REv. I049. See also Berle, Non-Voting Stock and "Bankers' Control" (I926) 39 Harv. L. REv. 673. There is current an extra-corporate "trust" notion which holds that business corporations have "a social service as well as a profit-making function" and specifically have fiduciary obligations to their employees, customers and to the general public. See Dodd, For Whom are Corporate Managers Trustees? (I932) 45 HARv. L. REV. II45. Cf. Berle, For Whom Corporate Managers are Trustees (I932) 45 HARV. L. REV. 1365.

c7 Book Review (I929) 38 Y ALE L. J. roo3.

$\approx$ Book Review (1929) 42 HARv. L. REv. 7I4. Mr. Kline also suggests that "any movement to increase the power of stockholders as such runs counter to the historical evolution of corporations." Modern stockholders want dividends-not control!

${ }^{2}$ Meeker v. Winthrop Iron Co., supra note 2; Farmers' Loan \& Trust Co. v. N. Y. \& N. R. Co., I50 N. Y. 4 I0, 430,44 N. E. I043, 1048 (I896); Jones v. Missouri-Edison Elec. Co., supra note I5, at 771 ; Kidd v. New Hampshire Traction Co., 74 N. H. I60, I78, 66 Atl. I27, I36 (IgOI). If the fact of control be there, the technique or manner of its exercise is of no importance. Southern Pacific Co. v. Bogert, 250 U. S. 483, 492, 39 Sup. Ct. 533, 537 (1919). A minority may occupy the position of trustee if it in fact controls (for instance, with the aid of proxies). Hyams v. Calumet \& Hecla Mining Co., 22I Fed. 529, 54I (C. C. A. 6 th, I915).

${ }^{60}$ Wood, The Status of Management Stockholders (I928) 38 YALE L. J. 57. In Wheeler v. Abilene Natl. Bank Bldg. Co., I59 Fed. 39I (C. C. A. 8th, I908), the court said, at 393-4: "The holder of the majority of the stock of a corporation has the power, by the election of biddable directors and by the vote of his stock to do everything that the corporation can do. His power to control and direct places him in its shoes, and constitutes him the actual, if not the technical trustee for the holders of the minority of the stock." But in that case the majority of the stock was owned by one person who was also a director 
"Authorities have been cited to support the proposition that an individual or a corporation holding a majority of the capital stock of another corporation sustains, by reason of such holding a fiduciary relation to the minority stockholders. But these authorities only hold, in effect, that the fiduciary relation arises when the majority stockholder assumes control of the corporation and dictates the action of the directors. The majority stockholder is not made a trustee for the minority stockholders in any sense by the mere fact that he holds a majority of the stock, or by the further fact that he uses the voting power of his stock to elect a board of directors for the corporation. The majority stockholder does not necessarily control the directors whom he appoints, and, in fact, he has no right to control them, and if they are controlled by him, they may be violating their duty, for which he also may be liable. . . . No liability of the majority stockholder to the minority stockholder for the misdeeds of his common trustees-the directors-can arise from the mere fact that the majority stockholder had the power to appoint, or, in fact, did appoint, these trustees. Such liability, however, may arise if the majority stockholder has made the derelict trustees his agents and dictated their conduct and thus caused a breach of fiduciary duty." 31

Since courts of equity will concededly restrain fraudulent conduct on the part of those in control of a corporation, the question of whether or not they should be deemed trustees may seem at inrst impression inconsequential. The answer to the question has, however, serious practical consequences. Cases of so-called "actual fraud" are not frequent and when they do arise, they are not difficult of solution. In close cases the decision may well depend upon whether the court approaches the facts from the point of view that the defendants are trustees for the plaintiffs. If it does, it will judge their conduct by "the punctilio of an honor the most sensitive" instead of merely by "the morals of the market place". ${ }^{32}$ If the defendants be trustees the burden of justifying their conduct is upon them. ${ }^{33}$

Having made our obeisance to principles we can proceed with an examination of typical fact-situations which have confronted the courts in applying them.

and president of the corporation. See also Tefft v. Schaeffer, I48 Wash. 602, 269 Pac. 1048 (I928) ; Harrison v. Thomas, II2 Fed. 22 (C. C. A. 5th, Igor); Hiscock v. Lacy, 9 Misc. $578,590,30$ N. Y. Supp. 860, 868 (I894). The UNIFORM BusINESS CoRPoratTon ACT, 9 U. L. A. (1932), approved by the American Bar Association in (1928) 53 A. B. A. R. 92, provides, in \$ 28 II, that holders of voting stock "stand in a fiduciary relation to the entire body of shareholders" if there be non-voting stock.

${ }^{31} 64$ N. J. Eq. 673, 689-690, 53 Atl. 842, 848 (1903).

22 "A trustee is held to something stricter than the morals of the market place. Not honesty alone, but the punctilio of an honor the most sensitive, is then the standard of behavior", Cardozo, C. J., I in Meinhard v. Salmon, 249 N. Y. 458,464, I64 N. E. 545,546 (1928). It has been asserted that courts do, and should, lag behind ethics. Swaine, stupra note 27 .

${ }^{23}$ Geddes v. Anaconda Mining Co., 254 U. S. 590, 4I Sup. Ct. 209 (I92I) ; Ross v. Quinnesec Iron Mining Co., 227 Fed. 337 (C. C. A. 6th, I9I5) ; Hyams v. Calumet \& Hecla Mining Co., supra note 29, at 540; Harrison v. Thomas, supra note 30 , at 29 ; Booth v. Land Filling \& Imp. Co., 68 N. J. Eq. 536, 59 Atl. 767 (I905); Sage v. Culver, 147 N. Y. 24r, 247, 4I N. E. 5I3, 514 (1895). Cf. Wentz v. Scott, Io F. (2d) 426 (C. C. A. 6th, 1926). 
Dividends, ${ }^{34}$ salaries, etc.

Since the primary desire of stockholders is to receive dividends, it is readily understandable why the resort to the courts to obtain them is so frequent. At the same time it is in this field, which is essentially entirely one of business policy, that the power of the directors comes closest to being absolute.

The earliest cases took the view that the courts were powerless to interfere, ${ }^{35}$ except, of course, in cases of fraud. ${ }^{36}$ Until this day the unwillingness to interfere persists, ${ }^{37}$ tempered by the view that equity should act where there is a clearly "improper" refusal to declare dividends. ${ }^{38}$ One of the carliest cases wherein a court compelled the declaration of a dividend is Hiscock $v$. Lacy. ${ }^{39}$

The corporation there involved was a national bank whose capital was represented by 4,000 shares of which the defendant owned a majority and the plaintiff $I, 243$. For years the bank had paid regular dividends of 8 to Io per cent. In I887 some differences arose between the plaintiff and the defendant and the plaintiff caused certain corporate action to be taken which was highly disagreeable to the defendant. Chagrined, the defendant quietly accumulated stock until in 1889 he owned a majority thereof and proceeded to elect a board of directors of his own choosing, and to remove the plaintiff entirely from the management of the bank. The directors whom he elected were either relatives, nominees or the owners of an insignificant

${ }^{3}$ See Wormser, May the Courts Compel the Declaration of a Corporate Dividend (19r8) 3 So. L. Q. 28I. For collection of cases, see II FLETCHER, op. cit. supra note $6, \$ \$ 5325-5327$. We shall here deal only with the rights of common stockholders. The holders of preferred stock are on a somewhat different footing. See Wabash Ry. Co. v. Barclay, 28o U. S. Ig7, 50 Sup. Ct. I06 (I930); Cratty v. Peoria Law Lib. Ass'n, 219 IIl. 516, 76 N. E. 709 (1906); Scott v. Baltimore \& Óhio R. R. Co., 93 Md. 475, 49 Atl. 327 (I90I) ; N. Y. L. E. \& W. R. R. v. Nickals, IIg U. S. 296, 7 Sup. Ct. 209 (I886); Boardman v. Lake Shore \& M. So. Ry., 84 N. Y. 157 (I88I); Storrow v. Texas Cons. Co. etc. Ass'n, 87 Fed. 6Iz (C. C. A. 5th, I898); Hastings v. International Paper Co., I87 App. Div. 404, 175 N. Y. Supp. 815 (IgIg); Pardee v. Harwood Elec. Co., 262 Pa. 68, I05 Atl. 48 (I9I8). Berle, op. cit. supra note 17 , c. v. and vi; Berle, supra note 26 , at I060; Note (1932) 45 HARV. L. REv. I374-I376. As to rights of policy holders in mutual life insurance companies, see Russell v. Washington Life Ins. Co., 62 Misc. 403, II5 N. Y. Supp. 950 (Ig0g).

ज State v. Bank, 6 La. 745 (I834); Williams v. Western Union Tel. Co., 93 N. Y. I62, I92 (I883); McNab v. McNab \& Harlin Mfg. Co., 62 Hun 18, I6 N. Y. Supp. 448 (I89I), aff'd I33 N. Y. 687, 3I N. E. 627 (I892).

$\approx$ Anderson v. W. J. Dyer \& Bros., 94 Minn. 30, ror N. W. I06r (I904); Burden v. Burden, I59 N. Y. 287, 308, 54 N. E. I7, 23 (1899). Of course, in order to obtain dividends it must appear that there is an available surplus. See Liebman v. Auto Strop Co., 24I N. Y. 427 , 150 N. E. 505 (1926) (involving the distribution of stock in another corporation as a dividend). But the mere showing of a large available surplus is not, per se, sufficient to -move a court to intervene. Burden v. Burden, supra; Trimble v. Amer. Sugar Ref. Co., 6 I N. J. Eq. 340, 48 Atl. $9 \mathrm{Iz}$ (Igor). Cf. Griffing v. A. A. Griffing Iron Co., 6I N. J. Eq. 269,48 Atl. 9ro (I9OI). As a condition precedent to relief from the courts the complaining stockholder must also show that he has exhausted his remedies within the corporation. Wilson v. American Ice Co., 206 Fed. 736 (D. N. J. I913).

${ }^{37}$ Marks v. American Brewing Co., r26 La. 666, 52 So. 983 (I9I0) ; Miller v. Crown Perfumery Co., I25 App. Div. 88I, I Io N̂. Y. Supp. 806 (Ig08); Hlawati v. Maeder-Hlawati Co., $289 \mathrm{~Pa}$. 233, I37 Att. 235 (1927).

"s Stevens v. U. S. Steel Corp., 68 N. J. Eq. 373, 377, 59 Atl. 905, 907 (1905).

$\approx$ Sipra note 30 . 
number of shares. In the aggregate the entire board exclusive of the defendant, did not own more than 200 shares. They immediately adopted defendant's announced policy not to declare dividends. The salaries of defendant's friends were increased, so that the expenses of the bank were doubled. There was no ready market for the stock and the defendant was unwilling either to sell his stock or buy more. Admittedly, the bank was able to pay dividends. It had a surplus equal to 50 per cent. of its capital, which was more than it had been during the years when dividends were paid. Under these circumstances the court found that the refusal to declare dividends was "without reasonable cause and in bad faith for the purpose of punishing the minority interest" and that although the defendant was not guilty of "intentional fraud" the plaintiff was entitled to redress. A dividend of not less than I2 per cent. was ordered. ${ }^{40}$

Probably the most famous dividend case is that which involved the Ford Motor Company, before Henry Ford bought out the minority. ${ }^{41}$

The Ford Motor Company was organized in I903 with an initial capital of $\$ 100,000$, representing $\$ 49,000$ in cash and $\$ 51,000$ in property. Stock was issued to Henry Ford, the Dodge brothers, James Couzens and several others. By I908, without further investment by the stockholders, its capital stock was increased to $\$ 2,000,000$. In addition to regular monthly dividends of 5 per cent., the company paid special dividends which for the years I9I I-I9I 5 aggregated $\$ 4$ I,000,00o. Despite these dividends, the corporate surplus in I9r6 was almost $\$ \mathrm{II} 2,000,000$, of which almost $\$ 54,000$,ooo was in cash. For the year ending July $3 \mathrm{I}$, I9I6 the profits were almost $\$ 60,000,000$. At this time Henry Ford owned 58 per cent. of the capital stock of the company and controlled its policies. He announced that since all the stockholders had received back in dividends more than they had invested, no further special dividends would be paid but that all earnings, above the regular dividend of 5 per cent. per month, would be put back into the business for the purpose of extending the business and employing more men at better wages. He also adhered to the policy of reducing the sales price of the cars so that from an original price of $\$ 900$, the sales price in August I9I6 was \$36o. In furtherance of Henry Ford's expansion program, the company undertook the purchase of iron mines and ships, the building of steel foundries and the now well-known River Rouge plant. No special dividend having been paid since October I9I5, the plaintiffs, owning

${ }^{60}$ For similar cases see Crichton v. Webb Press Co., II3 La. 167, 30 So. 926 (I904); Channon v. H. Channon Co., 2I8 I11. App. 397 (1920) (motive for non-dividend policy in family quarrel. Dividend ordered.). Cf. City Bank Farmers Trust Co. v. Hewitt Realty Co., 257 N. Y. 62, I77 N. E. 309 (I93 I), where the court refused to order a dividend, finding justifiable business reasons for non-declaration notwithstanding family quarrel.

a1 Dodge v. Ford Motor Co., 204 Mich. 459, I70 N. W. 668 (I9I9). Of course, this case is hardly "typical" but, since the courts have generally declined to intervene except in special circumstances, it seems preferable to consider in detail cases where the court did act rather than the many where it did not. 
about Io per cent. of the capital stock, protested and receiving no satisfaction, brought suit to enjoin the expansion program and to compel the distribution of 75 per cent. of the cash surplus to stockholders. Mr. Ford's testimony confirmed the view that he was being motivated in his policies by "certain sentiments, philanthropic and altruistic, creditable to Mr. Ford" or, as the plaintiffs charged, he proposed to run the corporation as "a semieleemosynary institution and not as a business institution". The trial court enjoined the expansion program and decreed the declaration of a dividend equal to 50 per cent. of the cash surplus. On appeal the injunction as to the expansion program was reversed because "the experience of the Ford Motor Company is evidence of capable management" and "judges are not business experts" but the decree as to dividends was affirmed. In justification, the court said:

"The difference between an incidental humanitarian expenditure of corporate funds for the benefit of the employees, like the building of a hospital for their use and the employment of agencies for the betterment of their condition, and a general purpose and plan to benefit mankind at the expense of others, is obvious. . . . A business corporation is organized and carried on primarily for the profit of the stockholders. - . . There is committed to the discretion of directors, a discretion to be exercised in good faith, the infinite details of business, including the wages which shall be paid to employees, the number of hours they shall work, the conditions under which labor shall be carried on, and the prices for which products shall be offered to the public. . . . It is not within the lawful powers of a board of directors to shape and conduct the affairs of a corporation for the merely incidental benefit of shareholders and for the primary purpose of benefiting others." 42

It is most unusual to find corporate managers diverting funds to social purposes rather than pay dividends, but it is not infrequent that corporate funds are paid out as "salaries" rather than to minority stockholders as dividends. Most of the cases involving salary questions turn on the selfinterest of the directors who voted them ${ }^{43}$ but some go further.

In Godley v. Crandall \& Godley Co., ${ }^{44}$ it appeared that a closely owned corporation was paying to its directors and certain other employee-stockholders 9 per cent. on their capital stock in addition to dividends of 6 per cent. received by all stockholders. At the suit of a minority stockholder recovery of this 9 per cent. was had notwithstanding the fact that it had been

4204 Mich. at 506-507, I70 N. W. at 684. See Dodd, supra note 26; Note (I9I9) 3 A. L. R. 443. As to the right to sell products below cost see Matter of Pierson, 44 App. Div. 215, 60 N. Y. Supp. 671 (I899); Trimble v. American Sugar Ref. Co., supra note 36.

${ }^{43}$ See SpelcmaN, op. cit. supra note 17. In Tefft v. Schaeffer, supra note 30, an unsuccessful attempt was made to apply the rule against a director voting salary to himself to a director voting salary to a majority stockholder when he, the director, owned only one share. $C f$. Harrison v. Thomas, supra note 30 ; Hiscock v. Lacy, suprai note 30.

${ }_{4}$ 2I2 N. Y. I2I, IO5 N. E. 8I8 (I9I4). 
denominated by the directors as "additional salaries" and its payment ratified by the defendants in their capacity of majority stockholders. ${ }^{45}$

In Heublin v. Wight, ${ }^{46}$ the court undertook to pass in detail upon salaries paid. It recognized the validity of the general principle that courts would not review salary action taken by the majority however "unwise or mistaken" they considered it but held it inapplicable to a case where the majority stockholders were the very ones to receive the salaries in question. The court considered, among other things, the annual profits of the corporation, the contributions of capital made by the stockholders and the returns received by them thereon, the work done by the defendants and by other employees, the salaries of other employees and prior salaries of the defendants. The court fixed a salary for each of the defendants and on appeal ${ }^{47}$ the decree was affirmed. In response to appellants' contention that even if the salaries were excessive the court could only order their return and not fix future salaries by "perpetual injunction", the court "assumed that the decree is based on and has application only to existing conditions [and that] if those conditions should undergo material change, so that large earnings were realized under efficient and capable management, the payment of proper and reasonable salaries though greater than the amounts fixed by the decree would not be prohibited by the injunction now in force".

New stock issies, sale of unissued stock, etc.

The most general equitable limitation upon the power of directors to issue new stock is found in the doctrine of pre-emptive rights. ${ }^{48}$ The exceptions which have been grafted on the doctrine and the radical differences between the corporations of today with their complicated financial and voting set-ups and the corporations of 1807 when the doctrine was first enunciated 49 have induced a trend away from arbitrary rules towards the view that the rights of stockholders should be measured by considerations of fairness in each case rather than by dogma. In view of this tendency and the prevalent practice of stipulating against pre-emptive rights in certificates of incorporation, we shall here confine our discussion to a few cases that passed on the facts involved from the point of view of equity rather than the rules of pre-emptive rights.

${ }^{\star 5}$ See Scott v. Lorillard Co., I0\& N. J. Eq. 153, I54 Atl. 515 (193r), aff'd 109 N. J. Eq. 417, I57 Atl. 388 (I93I).

${ }_{10} 527$ Fed. 667 (D. Md. I9I 5). See also Backus v. Finkelstein, 23 F. (2d) 53I, 536-7 (D. Minn. I924). In the further course of that litigation it was held that the defendants had forfeited all right to compensation by acts in breach of trust. $23 \mathrm{~F}$. (2d) 360-36I (D. Minn. I927). Cf. Jacobson v. Brooklyn Trust Co., I84 N. Y. I52, I6I-2, 76 N. E. I075, ro78 (I906), where the court refused to give consideration to the prosperity of the corporation.

${ }^{47} 238$ Fed. 32I (C. C. A. 4th. Ig16).
${ }^{4}$ See Morawetz, Preemptive Right of Shareholders (I928) 42 HARv. L. REv. I86; Frey, Shareholders' Preemptive Rights (1929) 38 YALE L. J. 563; Drinker, The Preemptive Right of Shareholders to Subscribe to New Shares (I930) 43 HARv. L. REv. 586; Berle, supra note 26 , at 1050-1060.

${ }^{4}$ Gray v. Portland Bank, 3 Mass. 363 (1807). 
In Luther v. C. J. Luther Co., ${ }^{50}$ the board of directors voted to sell thirty-nine shares of unissued original stock to the individual defendants, who at the time controlled the board, in spite of the fact that a majority of the outstanding stock was owned by the plaintiffs. The result of the sale was to vest a majority of the authorized stock in the defendants. The board determined, in the opinion of the trial court "honestly", that control of the corporation in the plaintiffs would be dangerous to the corporation and against its best business interests. The appellate court treated the stock as "mere property over which the powers of the directors are the same as over any other assets of the corporation" and therefore not subject to preemptive rights, but held nevertheless that the sale, its purpose being to take control from one faction and give it to another, was in breach of the duty of the directors not "to dispose of or manage property of the corporation to the end and for the purpose of giving to one part of their cestuis que trustent a benefit and advantage over, or at the expense of, another part". The stock was ordered returned to the corporation against repayment of the sale price.

In a recent New York case ${ }^{51}$ the court was guided by the same principles but reached an opposite result because of the presence of other factors. The corporation had seventy-six unissued shares and its board voted fifty thereof to one Graham at par in payment of a debt due him and the remaining twenty-six shares to one Ageno, a director, for cash, which it used to pay another debt. No opportunity was given to any other stockholder to subscribe. Graham thereafter transferred his shares to Ageno's sister, who was also a director. . As a result, Ageno's faction had control of the corporation. The plaintiffs, minority stockholders, sued to compel return of the stock and to restrain the voting thereof. The trial court found that the issue was in good faith to satisfy debts rather than to shift control. In support of this conclusion it was noted that at the time of their issuance there was no active contest for control, that the stock was sold for full value, and that the twenty-six shares issued to Ageno did not carry control. On appeal the Court of Appeals stated that even when no pre-emptive right exists "directors may not authorize the issue of unissued stock to themselves for the primary purpose of converting them from minority to majority stockholders", but affirmed the lower court's dismissal of the complaint on the ground that, on the findings of the trial court, there was no "breach of trust" and that minority stockholders may not in the absence thereof interfere in questions of business management.

${ }^{5}$ I I8 Wis. II2, 94 N. W. 69 (Ig03). See also Elliott v. Baker, I94 Mass. 5I8, 80 N. E. 450 (1907). The court there suggests that where there is a contest for control the directors should take advantage of the fact to get higher prices for unissued stock.

n Dunlay v. Avenue M. Garage \& R. Co., 253 N. Y. 274, 17o N. E. 9I7 (1930). Cf. Essex v. Essex, I4I Mich. 200, 104 N. W. 622 (Ig05). 
The directors of the International Silver Company, who owned preferred stock but no common stock, proposed to issue common stock at $\$ 50$ a share to both preferred and common stockholders on the same basis. Because there were more shares of preferred than common then outstanding, most of the new stock would go to the holders of preferred stock. By the certificate of incorporation of the company, the preferred stock was entitled on dissolution only to par and the common stock was entitled to the remainder. At the time of the proposed issuance the company had a large surplus. On the application of common stockholders, the court held the result would be unjust to the common stockholders and granted a preliminary injunction restraining the issue. ${ }^{.2}$

The subsequent history of this stock issue is of interest. After the granting of the preliminary injunction against the directors' original plan, it having been contended by plaintiffs that the common stock was worth very much more than $\$ 50$ a share, the directors proposed to sell the stock to the highest bidder. A preliminary injunction to restrain this was denied. ${ }^{53}$ The court took the view that the method proposed was proper to realize full value for the shares (indicating, however, that the directors would not be permitted to turn to their own advantage information not available to other bidders) and that therefore it ought not to interfere with the board's discretion as to method or even on the question whether there was any need for selling the stock merely because the board's motives might be suspect.

Even under the broadest powers in the directors as to the consideration for which they may issue stock, a court of equity will intervene where the consideration fixed is unfair to existing stockholders. ${ }^{54}$ Thus, there may not be unfair discrimination between different classes of stockholders as to the prices at which they may purchase the same kind of stock unless such difference in price is justified by business reasons. ${ }^{55}$

"While an arbitrary sale of the same issue of stock at different prices to different persons [even non-stockholders] would not be sanctioned, such differential sales will be sustained if based on business and commercial facts, which in the exercise of fair business judgment, lead directors to follow such a course." 56

\footnotetext{
${ }^{62}$ Borg v. International Silver Co., 2 F. (2d) gro (S. D. N. Y. x924).

${ }^{53}$ Borg v. International Silver Co., II F. (2d) I43 (S. D. N. Y. I925), aff'd II F. (2d) I47 (C. C. A. 2d, I925).

${ }^{4}$ Bodell v. General Gas \& Elec. Corp., I5 Del. Ch. Irg, I32 Atl. 442 (1926), aff'd I5 Del. Ch. 420, I40 Atl. 264 (I927); Atlantic Refining Co. v. Hodgman, 13 F. (2d) 78I (C. C. A. 3d. 1926), rev'g 300 Fed. 590 (D. Del. 1924).

${ }^{5}$ Bodell v. General Gas \& Elec. Corp., supra note 54. The court refused to interfere with the action of the board, finding that the financial justification offered by the directors for selling stock to different classes of existing stockholders at different prices was not "unwarranted and unfair", and that the directors acted "for what they believed to be the advantage of the corporation and all its stockholders."

${ }^{28}$ Atlantic Ref. Co. v. Hodgman, supra note 54, at 788. Here too the action of the board was not disturbed.
} 
The result of the foregoing cases seems to be that, in addition to the limitations imposed by the doctrine of pre-emptive right, directors may not exercise their power to issue new stock or sell treasury stock

(a) for the purpose of shifting control of the corporation; but courts will not intervene where the change of control is merely an incidental result of the issue which was made in good faith for business reasons;

(b) except at fair prices;

(c) so as to modify unfairly the existing relative rights of different classes of stockholders in the corporate property;

(d) at different prices to different persons unless justified by business reasons.

Purchase of stock; its own and that of other corporations.

The first problem in connection with the right of a corporation to purchase its own stock is one of power, but with that we are not here concerned.57 Assuming the existence of the power, what are the limitations upon its exercise? 58 The cases involving solvent corporations and therefore excluding questions of creditors' rights and of the right to purchase except out of surplus are few. ${ }^{59}$ Where fraud appears, the purchase will be enjoined. ${ }^{60}$ On the other hand, where the action is taken in good faith to aid the corporation, the purchase will be sustained. ${ }^{31}$ Apparently there is no need to permit all stockholders to sell merely because the privilege is given

"See Wormser, The Pozer of a Corporation to Acquire Its Own Stock (I9I5) 24 YALE L. J. 177. Cases are collected in 5 Thompson, Corporations (3d ed. I927) \$\$ 4081-2.

${ }^{2}$ See Levy, Purchase by a Corporation of Its Ozm Stock (1930) 15 Minn. L. R. I, for a discussion of this question from the standpoint of creditors as well as of dissenting stockholders. Mr. Levy concludes that the legitimate objects of re-purchase can be achieved in other ways, that the power is subject to abuse, that the resort to equity is an inadequate remedy, and that, therefore, the power should be denied by statute. The present writer does not concur in this uitimate conclusion. The New York Stock Exchange requires that listed investment trusts do not purchase their own common stocks except "under exceptional and special circumstances". "The primary object appears to be the prevention of trading in the companies own stock. "The employment of corporate funds to speculate in the stock of the company to which the funds belong is not a practice to be encouraged." Coleman v. Columbia Oil Co., 51 Pa. 74 (1865).

${ }^{2}$ For discussions of the rights of stockholders among themselves when the purchase is not out of surplus, see Grasselli Chemical Co. v. Aetna Explosives Co., 253 Fed. 66 (S. D. N. Y. I9I8) ; Barrett v. Webster Lumber Co., 275 Mass. 302, I75 N. E. 765 (I93I). Purchases except out of surplus are in some jurisdictions expressly prohibited. See N.Y. PENAL LAW (1909) \$664

${ }^{\infty}$ Lowe v. Pioneer Threshing Co., 70 Fed. 646 (C. C. D. Minn. 1895). This is so even if the action be taken under the guise of capital reduction proceedings. Theis v. Durr, I25 Wis. 651,104 N. W. 985 (1905).

or Ruffner v. Sophie Mae Candy Corp., 35 La. App. I14, I32 S. E. 396 (Ig26) ; Copper Belle Mining Co. v. Costello, II Ariz. 334, 95 Pac. 94 (I908); Gilchrist v. Highfield, I40 Wis. 476,123 N. W. $102(1909)$ 
to one. ${ }^{62}$ But funds properly ascribable to one class of stock, e. g., accrued dividends, may not be used to retire stock of another class. ${ }^{63}$

The terminology of the opinions in cases involving the purchase of stock of other corporations is such that any attempt to segregate rigidly the problem of power from that of the abuse thereof is difficult. The courts seem to say that when the object or purpose of the purchase is proper the corporation has the power to make it but that when the end is improper the purchase is ultra vires. It would perhaps be simpler, and certainly more consistent with present day charters and practice, to recognize freely that corporations have the power to purchase stock in other corporations, but that its exercise will be restrained if abused to the injury of one entitled to complain. A traditional standard for judging the propriety of a stock purchase was whether or not it would aid the authorized business of the corporation, but.with the present-day use of multi-power clauses in charters and the interdependence of business its sufficiency is rapidly passing. ${ }^{64}$ An older case which discussed the subject in terms of ultra vires but which actualiy applied equitable criteria to a stock purchase is Robotham v. Prudential Insurance Company. ${ }^{65}$ The insurance company was authorized to purchase stock in other corporations for "investment". The directors sought to purchase a majority of the stock of a trust company under an arrangement whereby the trust company would simultaneously acquire stock control of the insurance company. The result would be that the board of the insurance company, by virtue of their power to vote the trust company's stock, would become self-perpetuating. The court found that the "control" feature rather than the "investment" element was uppermost in the minds of the directors and, at the suit of a minority stockholder of the insurance company, enjoined the purchase. ${ }^{66}$ While the court referred to the high price being paid for the stock and its low yield, it is reasonable to assume that if the "control" scheme were absent the court would have refused to interfere with the action of the board in the exercise of its business judgment. This is exactly what a court of the same state did in the case of one corporation purchasing the stock of a competing company. ${ }^{67}$

${ }^{62}$ Wisconsin Lumber Co. v. Telephone Co., I27 Iowa 350, I0I N. W. 742 (I904). See also Dupee v. Boston Water Power Co., II4 Mass. 37 (I873); Barrett v. W. A. Webster Co., supra note 59. This of course assumes the absence of "fraud". See Lowe v. Pioneer Threshing Co., supra note 60; also cases cited I4a C. J. 280, note 9I. Cf. General Investment Co. v. American Hide \& Leather Co., 98 N. J. Eq. 326, I29 At1. 244 (I925), to the effect that a corporation buying stock for retirement must purchase ratably from all stockholders. Shares of stock are not retired by mere purchase. 5 Thompson, Corporations (3d ed. 1927) $\$ 4084$. Capital reductions must be effected ratably between all stockholders. See Note (rg26) 44 A. L. R. 35.

${ }^{*}$ General Inv. Co. v. American Hide \& Leather Co., supra note 62.

os For collection of cases on power of corporations to purchase and hold stock, see 5 Thompson, CoRporatrons ( 3 d ed. I927) $\$ \$ 4063-4077$.

Supra note $3 \mathrm{I}$.

${ }^{\infty}$ To like effect, Anglo-American Land M. \& N. Co. v. Lombard, r32 Fed. 72I (C. C. A. 8th, I904).

of Ellerman v. Chicago Junction Rys. etc. Co., supra note I2. But it was later charged by another minority stockholder that the Ellerman suit was collusive. The charge was 
Amendment of by-laws.

A court will, of course, refuse to interfere with the adoption by the majority of a by-law dealing with ordinary administrative or business matters. $^{\text {Bs }}$ On the other hand, where it is clear that action under the proposed by-law would necessarily be improper a court may enjoin its adoption. Thus stockholders were enjoined from voting upon an amendment to the by-laws of the corporation so as to provide for extra dividends to stockholders who were also employees, notwithstanding the assertion that the proposed plan was merely one fixing extra compensation to employees. ${ }^{69}$

An early leading case laid down the principle that "vested rights" may not be taken from minority stockholders without their consent by by-law amendments. ${ }^{70}$ In that case the capitalization of the corporation was fixed by the by-laws which provided for their amendment by the majority of the stockholders. Originally there was only one class of stock and the court held ${ }^{71}$ that a second class, preferred as to dividends, could not be created, even though offered to all stockholders upon the same terms, without unanimous consent. ${ }^{72}$

\section{Amendment of Charters. ${ }^{73}$}

We shall here not consider involuntary amendments imposed upon the corporation by the legislature ${ }^{74}$ but only those voluntarily adopted by the majority ${ }^{75}$ and shall assume that the power of amendment has been expressly reserved. ${ }^{76}$ Under such circumstances the only limitation which seems to have as yet received judicial sanction is that "vested rights" may not be destroyed. A claim to accumulated dividends is such a "vested

not sustained. Willoughby v. Chicago Junction Ry. Co., 50 N. J. Eq. 656, 669-676, 25 Atl. $277,282-284$ (1892).

${ }^{c}$ Burden v. Burden, supra note 36 (by-law giving extensive powers to general manager).

${ }^{\circ}$ Scott v. P. Lorillard Co., supra note 45. Cf. Rogers v. Hill, 60 F. (2d) Iog (C. C. A. 2d, 1932), sustaining a by-law granting to officers a percentage of net profit. But see dissenting opinion of Mr. Justice Stone in Rogers v. Guaranty Trust Co., 53 Sup. Ct. 295 (I933).

${ }^{70}$ Kent v. Quicksilyer Mining Co., 78 N. Y. I59 (I879).

${ }^{71} \mathrm{By}$ way of dicta; the decision was against the plaintiffs because of their laches, acquiescence, etc.

${ }^{2}$ The ruling was overcome by legislation permitting the creation of preferred stock by a two-thirds vote of stockholders. See Dresser v. Donner Steel Co., 247 N. Y. 553, 556-7, I6I N. E. I79, I80 (1928). The subject is now considered in connection with the amendment of charters rather than of by-laws, infra.

${ }^{73}$ See Dodd, Dissenting Stockholders and Amendments to Corporate Charters (1927) 75 U. oF PA. L. REv. 585, 723; Cades, Constitutional and Equitable Limitation on the Power of the Majority to Amend Charters (1928) 77 U. of PA. L. Rev. 256.

${ }^{7}$ The writer has in course of preparation an article on state control over corporations.

TThroughout this article we use the word "majority" to signify the percentage sufficient under the governing law to adopt a course of conduct, it may be $51 \%, 67 \%$ or $75 \%$.

${ }^{70}$ Nor shall we treat the right of a dissenting minority to compel the corporation to buy their stock at appraised values under statutes. See Levy, Rights of Dissenting Shareholders to Appraisal and Payment (1930) I5 CoRN. L. Q. 420 ; Robinson, Dissenting Shareholders: Their Raghts to Dividends and the Valuation of Their Shares (1932) 32 CoL. L. REv. 60; infra note 85 . 
right" that may not be wiped out by charter amendment. ${ }^{77}$ But a change in future dividend rights is not invalid. ${ }^{78}$ Thus in Davis $v$. Louisville Gas \& Electric $\mathrm{Co}^{79}$ the court refused to interfere with the adoption of an amendment altering the dividend rights of the Class $B$ stock and depriving it of other "material rights", and justified its position by accepting the view of the majority, acting in "good faith", that the best interests of the corporation required added benefits for the Class A stock.

\section{Sale, ${ }^{80}$ Consolidation, ${ }^{81}$ Reorganization ${ }^{82}$ and Dissolution. ${ }^{83}$}

While the various matters indicated by this sub-heading may be separate and distinct from each other, in practice most corporate transactions of the kind which will be here considered involve more than one. Much has already been written on this subject. ${ }^{84}$ Much of the discussion is, however, concerned with the existence of adequate power in the majority and its compliance with statutory and charter provisions. We here, as throughout this article, assume the most sweeping statutory and charter provisions and technical compliance with all their terms. The question of the

"Morris v. American Public Utilities Co., I4 Del. Ch. I36, I22 Atl. 696 (I923) ; Lonsdale Securities Corp. v. International Mercantile Marine Co., IOI N. J. Eq. 554, I39 Atl. 50 (I927). See also Colgate v. U. (S. Leather Co., 73 N. J. Eq. 72, 67 Atl. 657 (I907), rev'g 75 N. J. Eq. 227, 72 At1. I26 (I909). Cf. Windhurst v. Central Leather Co., infra note 90. Quaere, whether the benefit of a sinking fund requirement is such a vested right. In Yoakum v. Providence Biltmore Hotel Co., 34 F. (2d) 533 (D. R. I. I929), an amendment depriving a preferred stock of its sinking fund rights was held invalid, but it is not clear that the same result would have been reached if the court had held applicable a subsequently adopted statutory provision couched in broader terms.

${ }_{78}^{7}$ Davis v. Louisville Gas \& Electric Co., I6 Del. Ch. I57, I42 At1. 654 (I928); Peters v. U. S. Mortgage Co., I3 Del. Ch. II, II4 Atl. 598 (I92I). Nor is a change in "cumulative voting" provisions. Maddock v. Vorclone Corp., I47 Atl. 255 (Del. Ch. I929). And a change from par value to no par value stock is also valid. Randle v. Winona Coal Co., 206 Ala. 254, 89 So. 790 (I92r).

Supra note 78. The decision has been criticized. See Cades, supra note 73.

50 Meaning a voluntary sale of all or substantially all the assets of the corporation. The power to sell without unanimous consent will be assumed. See Warren, Voluntary Transfers of Corporate Undertakings (IgI/) 30 HARv. L. REv. 335.

"Including "merger".

\& The major problems in reorganizations arise out of the different rights of holders of different classes of securities and but rarely out of conflicts between security-holders of the same class. This is because the corporation is generally insolvent and the problem is to adjust the relative priorities. See Cravath, The Reorganization of Corporations, lecture delivered March 1916 and published in SOMe Legal Phases of Corporate Financing, ReORGANIzATION AND Regulation (I9I7) I35; Swaine, Reorganization of Corporations: Certain Developments of the Last Decade (1927) 27 CoL. L. REv. 90I. See Abbot v. Waltham Watch Co., 260 Mass. 81, 156 N. E. 8977. (I927). The writer has in course of preparation an article on creditor control of corporations.

${ }^{*}$ See Fain, Limitations of the Statutory Power of Majority Stockholders to Dissolva a Corporation (IgI2) 25 HaRv. L. Rev. 677. The right of the minority to compel dissolution will be considered hereafter in connection with the question of the form of relief which may be obtained in equity.

\&4 In addition to the articles cited supra notes $76-83$ see Lattin, Equitable Limitations on Statutory or Charter Powers Given to Majority Stockholders (1932) 30 MICE. L. REv. 645; Lattin, The Minority Stockholder and Intracorporate Conflict (1932) IT IowA L. BuLI. 3I3; Hills, Consolidation of Corporations by Sale of Assets and Distribution of Shares (I93I) I9 CALIF. L. REv. 349; Berle, supra note 26, at 1069-1072. There is a somewhat unique procedure in Pennsylvania. See Lauman v. Lebanon Valley R. R. Co., $30 \mathrm{~Pa} .42$ (I858), and the cases which have followed it and, as to preferred stock, Petry v. Harwood Electric Co., $280 \mathrm{~Pa}$. I42, I24 At1. 302 (1924). 
minority's right to redress in equity is also tied up with its rights under statutory provisions affording a right to compel the corporation to buy its stock at appraised value, ${ }^{85}$ but since those rights, except in a very few states by virtue of express provision in their statutes, are not deemed exclusive, and since the statutory right is not yet universal, it seems desirable to examine a few typical cases in equity not influenced thereby. Even if appraisal statutes come to preempt the field, these cases should be helpful in formulating general concepts as to equitable limitations upon majorities.

The majority having the power to sell all the corporate assets the courts will not review the "expediency" of such a sale but will intervene only to prevent or redress fraud. ${ }^{86}$ A sale at less than fair value is fraudulent. ${ }^{87}$

The Steel \& Tube case $^{88}$ is most instructive because of the detailed review of the testimony contained in the opinions. The plaintifts, owning about 20 per cent. of the common stock of Steel \& Tube Co., sued to enjoin a proposed sale of all its assets to Youngstown Sheet \& Tube Co. for about $\$ 73,000,000$. Control of the corporation was vested in a syndicate which owned about 60 per cent. of the common stock and some preferred stock. Prominent in the syndicate was a banking firm which had previously dis. tributed an issue of its preferred stock at $\$ 98$ a share. Under the terms of the proposed sale the preferred stock would be redeemed at $\$$ r ro a share. The plaintiffs charged that the syndicate had a selfish interest in putting through the sale in that it was their desire to liquidate their common stock holdings quickly and that the retirement of the preferred at \$rIo would greatly enhance the bankers' good will. The court did not consider this interest sufficient to vitiate their approval of the sale, but nevertheless granted a preliminary injunction on a showing that the book value of the assets was over $\$ 94,000,000$. Thereupon a hearing was had as to the adequacy of the price and on all the evidence the court dissolved the injunction be-

${ }^{8}$ See Wiener, Payment of Dissenting Stockholders (1927) 27 CoL. L. REv. 547 ; Lattin, Remedies of Dissenting Stockholders Under Appraisal Statutes (193I) 45 HARv. L. REv. 233; articles cited stipra note 76. For developments during I93I see Note (I932) 45 HARV. L. REv. I396-I403.

${ }^{80} \mathrm{~J}$. H. Lane Co. v. Maple Cotton Mills, 226 Fed. 692 (C. C. A. 4th, Igr5) ; on rehearing sale set aside because the directors were the purchasers, 232 Fed. 421 (C. C. A. $4^{\text {th, IgI6). }}$

${ }^{87}$ Hinds v. Fishkill \& Matteawan Gas Co., 96 App. Div. I4, 88 N. Y. Supp. 954 (I904). See Wheeler v. Abilene Nat. Bk. Bldg. Co., I59 Fed. 39 I (C. C. A. 8th, Ig08). Relief was granted in Geddes v. Anaconda Mining Co., supra note 33; Nave-McCord Mercantile Co. v. Ranney, $29 \mathrm{~F}$. (2d) 383 (C. C. A. 8th, Ig28). Relief was denied in Allaun v. Consolidated Oil Co., I47 Atl. 257 (Del. Ch. r929); Allied Chemical \& Dye Corp. v. Steel \& Tube Co., I4 Del. Ch. 1, 64, I20 Atl. 486, I22 Atl. I42 (1923); Wall v. Anaconda Copper Mining Co., 216 Fed. 242 (D. Mont. I9r4), aff'd sub nom. Wall v. Parrot S. \& C. Co., 244 U. S. 407, 37 Sup. Ct. 609 (Igr) . The result is frequently influenced by the court's determination as to where the burden of proof lies. While there is some conflict in the decisions, it is safe to assume that when the sale is to the majority itself or to those affiliated with it, the burden of justification will be on the defendants, Geddes v. Anaconda Mining Co., stipra, but that whenever the board is independent, and without a personal interest in the transaction, there is a presumption of fairness which the plaintiffs must overcome. Allied Chemical \& Dye Corp. v. Steel \& Tube Co., supra; Allaun v. Consolidated Oil Co., supra.

${ }^{3}$ Sippra note 87 . 
cause it was not satisfied that the discrepancy between the value of the assets and the sales price was so great "that it is to be attributed not to a difference of opinion upon a highly debatable question but rather to bad faith".

Merger terms too must be "fair".

The Equitable Life Assurance Society owned about 67 per cent. of the stock of the Equitable Trust Company and 49 per cent. of that of the Mercantile Trust Company, and proposed a merger of the two. Under the proposed terms, the new stock would be issued in the ratio of one for one of the old Mercantile stock and one for two of the old Equitable stock or $\$ 435$ in cash per share. It appeared that the book value of Mercantile was $\$ 45^{2}$ a share and that of the Equitable $\$ 440$. The court nevertheless refused to intervene at the suit of a minority stockholder of the Equitable and justified the difference in treatment of the two stocks by comparing the business situation of the two trust companies, the Mercantile earning 5 I per cent. on each share and the Equitable only 25 per cent. It also heeded pessimistic forecasts as to the future prospects of the Equitable. ${ }^{89}$

A preferred stockholder of Central Leather Company attacked the merger between that company and U. S. Leather Company on the ground that it was inequitable. For each share of preferred stock entitled to accumulated dividends of $\$ 43$ and 7 per cent. annual dividends ahead of the common, there was to be given $\$ 5$ in cash, one-half share of a new preferred stock entitled to dividends at the rate of $\$ 3.50$ per annum, and three-fourths share of a Class A stock having priority over the common stock in dividends to the extent of $\$ 3$ per annum. The court held the terms not inequitable in view of the financial conditions of the two companies. ${ }^{90}$

In Outwater v. Public Service Corp. ${ }^{91}$ the court did enjoin a proposed merger. The plaintiffs were minority stockholders in operating utilities whose properties were leased to a corporation which (through a subsidiary) owned the majority stock of the corporations. The leases were for 999 years at net rentals which assured dividends to the stockholders. The purpose of the proposed merger was to change the leaseholds into fees. The stockholders of each of the corporations were to receive for their common stock a 6 per cent. cumulative preferred non-voting stock on a basis that would afford them a slightly better yield than their common stock under the leases. The preferred stock was to be redeemable after three years.

${ }^{9}$ Colby v. Equitable Trust Co., supra note 15. Some of the facts appear in Morse v. Equitable Life Assurance Society, r24 App. Div, 235, I08 N. Y. Supp. 986 (I908). The court was unmistakably influenced by the fact that only $r \%$ of the Equitable stock was opposing the merger.

${ }^{\infty}$ Windhurst v. Central Leather Co., IOI N. J. Eq. 543, I38 At1. 772 (I927), aff'd IO7 N. J. Eq. 528 , I.53 Atl. 402 (I93I). Cf. Colgate v. U. S. Leather Co. and cases cited supra note 77. In MacFarlane v. North American Cement Corp., I57 Atl. 396 (Del. Ch. I928), a preferred stockholder unsuccessfully challenged a merger on the ground that the common stock was receiving an undue proportion of the consideration being received for the entire corporation.

${ }_{91}$ I03 N. J. Eq. 46I, I43 Atl. 729 (I928), aff'd I04 N. J. Eq. 490, I46 Atl. 9 I6 (I929). 
There was no "actual intent to defraud the minority". The court accepted as "an abstract proposition" that a court of equity has no right "to interfere in the internal affairs of the merging companies in the absence of fraud, actual or constructive", but was induced to grant the injunction primarily because of the redemption feature. This, in the view of the court, resulted in a compulsory sale of their common stock by the minority for the equivalent of a three year promissory note and was violative of the principle that "continued membership, until dissolution, is an inherent property right in corporate existence".

In another case ${ }^{92}$ a consolidation was held "unfair" and therefore a "legal fraud". The consolidation was between the Missouri-Edison Company and the Union Electric Company, both of which were controlled by the same interests. The attack on the consolidation was by a preferred stockholder of Missouri-Edison. The finding that the terms of consolidation were not fair to the plaintiff was the result of an analysis of the figures which disclosed that whereas the Union company contributed only $6 / 32$ nds of the combined assets, it received securities representing four-fifths thereof, and that although the Edison preferred stock was entitled to a prior claim on one-half of the combined assets, it received only $5 / 32$ nds.

The need for equality implicit in the Missouri-Edison case was some years later made explicit by the United States Supreme Court in Southern Pacific Co. v. Bogert. ${ }^{93}$ It there appeared that the Southern Pacific sought to incorporate into its own system the Houston \& Texas Central Railway, control of which it owned through a subsidiary, upon terms which would permit it to acquire the new stock to be issued for the property at $\$ 26$ a share, whereas others, including the minority stockholders, would be required to pay over $\$ 7$ I a share for the same stock. The court said:

"If through that control a sale of the corporation's property is made and the property acquired by the majority, the minority may not be excluded from a fair participation in the fruits of the sale. . . The essential of the liability to account sought to be enforced in this suit lies not in fraud or mismanagement, but in the fact that, having become a fiduciary through taking control of the old Houston Company, the Southern Pacific has secured fruits which it has not shared with the minority. The wrong lay not in acquiring the stock, but in refusing to make a pro rata distribution on equal terms among the old Houston Company shareholders." 94

The right to continue in the corporation suggested in the Outwater case may be sufficient to prevent dissolution by the majority. The statutory power to dissolve given to the majority may not be used to "freeze out" the mi-

Jones v. Missouri-Edison Electric Co., supra note 15 .

Supra note 29.

is Id. at 492, 34 Sup. Ct. at 537 . 
nority. Thus, in Godley v. Crandall \& Godley Co., ${ }^{95}$ an action for an accounting was sustained, the court finding that the action of the majority in discontinuing the business and liquidating it was in bad faith to enable a new corporation which they organized to acquire it. The "fiduciary" theory which underlies the limitation upon the majority's right to dissolve in "bad faith" was expressed by the New York Court of Appeals as follows:

"The directors, in reaching their belief [as to whether the dissolution is 'advisable'] cannot consider or give weight to their personal wishes, comfort or advantage. Whether or not the dissolution is wise or expedient for themselves as apart from the corporation or any or all of the other stockholders they can neither question nor determine. Their action must be based upon the belief that the interests and welfare of the corporation and the stockholders generally will be promoted by the dissolution. The belief may be erroneous or ill-founded, but it must be formed in good faith. . . . The relation of the directors to the stockholders is essentially that of trustee and cestui que trust. - . Undoubtedly no trust relation ordinarily exists between the stockholders themselves or between the stockholders and the corporation, because the stockholders, ordinarily, are strangers to the management and control of the corporation business and affairs. . . . The section 22I [General Corporation Law] imposes upon the stockholders the ultimate determination of the important question whether or not the corporation shall be dissolved forthwith. The stockholders are bound to determine and control this particular part of the corporation's affairs, in regard to which they occupy a relation of trust as between themselves and the corporation, and are burdened and restricted by fiduciary obligations. When a number of stockholders constitute themselves, or are by law constituted, the managers of corporate affairs or interests they stand in much the same attitude towards the other or minority stockholders that the directors sustain, generally, towards all the stockholders, and the law requires of them the utmost good faith. . . . In taking corporate action under the statute, the stockholders are acting for the corporation and for each other and they cannot use their corporate power in bad faith or for their individual advantage or purpose." 96

A contrary conclusion had been reached some seventeen years earlier by a federal court sitting in New Jersey. ${ }^{97}$ In that case the defendant corpo-

${ }^{\infty}$ Supra note 44 . See also Paine v. Saulsbury, 200 Mich. 58, 166 N. W. 1036 (1918), where the court refused a judicial dissolution at the request of the majority because the corporation was prosperous and the primary object of the dissolution was to get rid of the minority. Cf. Slattery v. Greater New Orleans Realty \& Dev. Co., I28 La. 87I, 55 So. 558 (I9II).

${ }^{\circ}$ Kavanaugh v. Kavanaugh Knitting Co., 226 N. Y. I85, I92, I94, 195, 123 N. E. I48, 15I, I52 (I9I9).

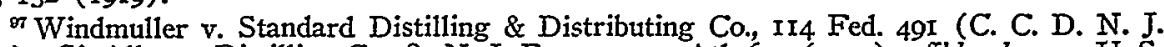
I902). Cf. Allen v. Distilling Co., 87 N. J. Eq. 53I, 100 Atl. 620 (I9I7), aff'd sub nom. U. S. Industrial Alcohol Co. v. Distilling Co., 89 N. J. Eq. I77, 104 Atl. 216 (rgI8). See also In re Pneumatic Tube Steam Splicer Co., 6o F. (2d) 524 (D. Md. I932), sustaining right of directors, who also are majority stockholders, to file voluntary petition in bankruptcy. 
ration owned a majority of the common stock of another corporation and had guaranteed the dividends on its preferred stock. The court refused to enjoin the dissolution of said corporation, at the suit of a preferred stockholder who claimed that the purpose of the dissolution was to avoid the guaranty, holding that stockholders are in no sense trustees for each other and are not to be barred from voting because of a personal interest in the matter.

In a still earlier case ${ }^{98}$ the court also held that it may not inquire into the "motives" which actuated the majority in its desire to dissolve the corporation, but held it liable to the minority for the fair value of the assets, the majority itself having acquired them. ${ }^{99}$

Were it not for the fact that in discussions as to the adequacy of equity to protect minorities the substantive principles are inextricably tied up with what may be briefly described as procedural questions, we might stop at this point for summation. Under the circumstances, however, to do so would be to tell but half the tale.

\section{II}

\section{Practice And Procedure}

Those who challenge the adequacy of the judicial relief available to minority stockholders do so primarily on the grounds of delay, expense, and "pitfalls". ${ }^{100}$ Occasionally it is urged that judges are incompetent to deal with business problenis.

Minority stockholders' suits are not the exclusive exemplars of the law's delays and hence it is not a special problem. ${ }^{101}$ Nor is judicial incompetence manifested only in corporate litigation. If the contention is that not even competent judges are able to deal with "business" problems, it is pointless. Courts must, as they are continuously doing, deal with business problems and the fact that corporate machinery may be involved does not alter the situation. The element of expense is undeniably serious for the small

${ }^{5}$ Ervin v. Oregon Ry. \& Nav. Co., 20 Fed. 577 (C. C. S. D. N. Y. I8\&4), appeal dismissed I36 U. S. 645, Io Sup. Ct. I072 (I889).

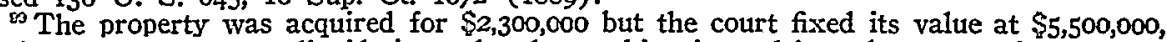
refusing to accept a mere liquidating value, but seeking instead its value as a going concern at the time of dissolution. Cf. Green v. Blunett, I ro S. W. 108 (Texas, Igo8); and Watkins v. National Bank, 5I Kan. 254, 32 Pac. 9I4 (1893), where the court refused to hold the defendants liable for "good will".

I60 "It is all very well to say that the minority stockholder has his redress if his company is being managed in an adverse interest. He hasn't. . . . Litigating against one of these powerful systems is an expensive business. The pitfalls and delays are endless. It is a luxury reserved for the large holders and then only when they have plenty of money and infinite patience." Samuel Untermyer, Some Neoded Legislative Reforms in Corporate Management, an address, New York County Lawyers' Assn., Jan. 5, IgIr. Professor Wormser is satisfied "that our courts have shown an intelligent realization of the implied obligations of corporate entities and their managers". Book Review (I933) I9 A. B. A. J. II3.

${ }^{102}$ Indeed, in many cases, as we shall hereafter see, preliminary and summary relief is obtainable pendente lite. 
stockholder acting alone but, generally, he need not act alone and may readily join with other stockholders in the same position. ${ }^{102}$ The advantage which the management has in its ready access to all information, in its business contacts, and in the availability of the corporate treasury cannot be gainsaid. ${ }^{103}$

The "pitfalls" presumably are to be found in the rules of practice and procedure, ${ }^{104}$ but before considering them it seems desirable to express a caution. A stockholder's suit is but a single step in what has been aptly described as a "campaign". It begins with the first efforts to obtain information from the corporation and very frequently ends, not with victory or defeat in the courtroom, but in a negotiated compromise. It is for this reason that the law reports do not give a full and complete picture of the struggle between majorities and minorities.

\section{The nature of the suit.}

Suits brought by individual stockholders are more or less indiscriminately referred to as representative, or as derivative, or merely as stockholders' suits. It would seem that they can be classified into three categories. There is the purely personal cause of action for the violation of a private right. In this category are suits to compel the transfer of stock, ${ }^{105}$ to enforce recognition of pre-emptive rights, ${ }^{106}$ or to recover damages for breach of a contract in favor of the stockholder. ${ }^{107}$ The remaining two categories involve the enforcement of corporate rights. One group consists of those cases where the suit is against a third person to recover a benefit for the corporation which it has itself refused to seek. ${ }^{108}$ In these "derivative" suits the corporation is a nominal defendant, sued because of its unwillingness to act as plaintiff, but the direct beneficiary of a victory by the plaintiff. ${ }^{109}$ The last group consists of those strictly intra-corporate suits where the plaintiff brings a "representative" suit on his own behalf and on behalf of all other stockholders similarly situated.

This attempt at cataloging is suggested merely as a convenient device for handling most situations and is not intended to indicate that all stockhold-

${ }^{102}$ See Rohrlich, Protective Committees (1932) 80 U. of PA. L. REv. 67o.

103 To some extent these advantages are balanced by the relative ease with which a minority stockholder with a plausible cause of action may force the maintenance of the status quo pendente lite when the management may desire immediate action. .

${ }^{10}$ In this section we shall of course assume familiarity with equity pleading and practice and shall discuss only a few special problems.

${ }_{105}$ E. g., Knox v. Terpezone Co., 215 N. Y. 259, 109 N. E. 250 (I9r5).

${ }^{108}$ E. g., Stokes v. Continental Trust Co., I86 N. Y. 285,78 N. E. 1090 (1906).

${ }^{107}$ E. g., Refusal to convert convertible stock: Marony v. Wheeling \& Lake Erie Ry. Co., 33 F. (2d) 916 (S. D. N. Y. 1929); Cheatham v. Wheeling \& Lake Erie Ry. Co., 37 F. (2d) 593 (S. D. N. Y. I930).

${ }^{100}$ E. g., Barr v. N. Y. L. E. \& W. R. R. Co., supra note I8. See Glenn, The Stockholder's Suit (I924) 33 YALE L. J. 580.

${ }^{102}$ At times the forces that caused the corporation to decline to sue may cause it actively, either openly or surreptitiously, to espouse the cause of the defendants. This is invariably true when the "third-party "defendants are the controlling directors. 
ers' suits çan be arbitrarily placed in one group or another exclusively. In litigation there is inevitable overlapping. A single stockholder's personal suit may determine a whole course of corporate conduct. So too the issues involved in a strictly intra-corporate conflict over policy may be presented to the courts in the form of a suit for an accounting against officers or directors and thus take on the procedural ear-marks of a case of the second group. Nor is it always possible to determine with exactness whether the right being asserted is a corporate or a personal right. A series of New York cases that have been the subject of much discussion ${ }^{110}$ may be used to delineate the problem that sometimes exists.

In Niles v. New York Central and Hudson River Railroad Company, ${ }^{111}$ the plaintiff, a stockholder of the New York \& Northern Railroad Company, sued to recover damages sustained by him as the result of an alleged conspiracy on the part of the defendants to procure the property of the New York \& Northern for the New York Central \& Hudson River. A demurrer to the complaint was sustained. The Court of Appeals took the position that the injury resulting from the wrongs of the defendants was to the corporation and that the depreciation in the value of plaintiff's stock was an incidental result of the injury sustained by the corporation. The court was influenced in denying direct relief to the plaintiff by the fact that corporate creditors had prior rights and that the recognition of plaintiff's cause would have given a similar cause of action to every stockholder. This decision was followed without much difficulty until General Rubber Co. v. Benedict. ${ }^{112}$ The General Rubber Company (of New Jersey) owned practically all of the capital stock of the General Rubber Company of Brazil. Benedict was a director of the plaintiff but not of the subsidiary company. The complaint charged that Benedict in violation of the obligations which he owed the plaintiff as one of its directors concealed from it the fact that an employee of the subsidiary company was misapplying that company's funds. The plaintiff asked damages for the amount by which the value of its shares of the subsidiary company was lessened as a result of the defalcations. The Appellate Division sustained the complaint by a $3-2$ decision. On a further appeal to the Court of Appeals the complaint was again sustained; this time by a 4-2 decision. The minority argued that the direct injury was to the subsidiary corporation and that the plaintiff as a stockholder had no right to sue for its indirect damage. The majority apparently distinguished the earlier cases by emphasizing that the obligation of the defendant to the plaintiff was by virtue of his position as director but that any liability of his to

${ }^{100}$ Note (IgI5) 28 HARv. L. REv. 409; (IgI6) 25 YALE L. J. I54; (Ig23) 23 CoL. L. Rev. 498; (I929) 42 HARv. L. REv. 705; Comment (I929) 38 YALE L. J. 965.

${ }_{17}$ I N. Y. II9, 68 N. E. I42 (Ig03). See also Major v. American Malt \& Grain Co., Ino Misc. I32, I8I N. Y. Supp. I52 (I920). Cf. Nave-McCord Mercantile Co. v. Ranney, supra note 87 .

${ }_{212} 215$ N. Y. 18,109 N. E. 96 (I9r5), aff'g 164 App. Div. 332, I49 N. Y. Supp. 880 (I9I4). 
the subsidiary corporation would exist, if at all, on an entirely different basis. In support of this distinction some reliance was placed upon Ritchic v. McMullen.113 In that case, one Ritchie, who had pledged corporate stocks and bonds with certain persons as collateral for a loan, alleged that they conspired to render his property valueless and in furtherance of that conspiracy mismanaged the corporation whose securities he had pledged. The court, per Taft, J., held the principle that a stockholder cannot obtain direct relief for injuries to the corporation inapplicable to the situation there presented because the wrongdoers owed Ritchie the direct duties of pledgees. These decisions induced the Supreme Court of Pennsylvania to sustain a complaint whereby an inventor sought to recover damages for alleged improper conduct on the part of the defendants with respect to a corporation to which the inventions had been assigned. ${ }^{114}$

On the authority of the General Rubber Company case, the New York Court of Appeals some years later sustained a claim against an administrator and his surety for loss sustained as a result of his peculations from a corporation in which the estate owned stock and in which he acted as officer and director, notwithstanding the fact that the corporation had itself recovered a judgment against him for the same misappropriation. ${ }^{115}$ The decision was not rendered without a powerful dissent which contended that decisions such as in the General Rubber and Ritchie cases can be regarded as sound only when the duty owing to the plaintiff is entirely different from that owing to the corporation and when the plaintiff's loss is not merely an indirect result of the injury to the corporation. ${ }^{116}$

If the wrong sought to be redressed be found to be a corporate injury certain consequences follow. The complaining stockholder may not sue for his own benefit but must sue for the benefit of the corporation. ${ }^{117}$ It is not sufficient to sue merely on behalf of such stockholders as may join, ${ }^{118}$ for the right is that of the corporation and not merely the joint right of the complaining stockholders. ${ }^{119}$ The judgment accordingly must be in favor of the corporation and not in favor of the plaintiffs. ${ }^{120}$ Under exceptional circumstances the plaintiffs may receive directly their proportionate interest in any recovery which would ordinarily go to the corporation. ${ }^{121}$

\footnotetext{
${ }^{113} 79$ Fed. 522 (C. C. A. 6th, 1897 ).

11 Vierling v. Baxter, 293 Pa. 52, I4I Atl. 728 (1928).

${ }_{115}$ Matter of Auditore, 249 N. Y. 335, I64 N. E. 242 (I928).

${ }^{10}$ See Green v. Victor Talking Machine Co.n 24 F. (2d) 378 (C. C. A. 2 d, I928), certiorari denied 278 U. S. 602, 49 Sup. Ct. 9 (1928).

${ }_{17}$ Davis v. Peabody, I70 Mass. 397,49 N. E. 750 ( 1898 ).

${ }^{218}$ Zinn v. Baxter, 65 Ohio St. 34I, 62 N. E. 327 (I90I).

${ }^{210}$ Endicott v. Marvel, 8I N. J. Eq. 378, 388, 87 Atl. 230, 234 (19r3), aff'd 83 N. J. Eq. 632,92 Atl. 373 (I9I4).

${ }_{120}^{2}$ Pollitz v. Wabash R. R. Co., I67 App. Div. 669, 152 N. Y. Supp. 803 (I9I5); Miller v. Crown Perfumery Co., supra note 37 ; Landis v. Sea Isle City Hotel Co., 53 N. J. Eq. 654, 33 At1. 964 (1895): Zinn v. Baxter, supra note II 8 and cases there cited.

${ }_{121}$ Dill v. Johnston, 72 Okla. I49, I79 Pac. 608 (I9I9) (corporation out of business, defendant had converted all corporate assets to his own possession). Cf. Thompson v. Stanley, 20 N. Y. Supp. 317 (1892). In Baillie v. Columbia Gold Mining Co., 86 Ore. I, I9,
} 
Asserting as he does a right not his own, the common-law side of the court will not hear the minority stockholder. ${ }^{122}$ But his right to sue in equity in a proper case was recognized long ago. ${ }^{123}$

It is generally stated that as a condition precedent to the maintenance of such a suit it must appear that redress cannot be obtained within the corporation, ${ }^{124}$ but in so far as intra-corporate controversies are concerned this requirement is not substantial. Proof of a prior demand is not insisted upon where the alleged wrongdoers are in control of the corporation or it is obvious that prior demand upon the corporation would have been futile. ${ }^{125}$

\section{Who may sue.}

The suit may be maintained only by one who is a stockholder at the time of the prosecution of the suit. ${ }^{128}$ This does not necessarily mean a stockholder of record, actual ownership is sufficient; ${ }^{127}$ as is ownership of

166 Pac. 965,970 (I9I7), the court said, "We have found a few cases in which stockholders have sued on behalf of themselves and all others similarly situated for the redress of wrongs done the corporation, in which the court has in effect directed a dividend, by requiring the unfaithful majority to Day the minority its aliquot share of moneys taken from the corporate treasury: (citing cases). The doctrine of these cases is applicable only where the court can say that the powers of the directors will be abused to the injury of the complaining stockholders and that the circumstances clearly call for the declaration of a dividend."

${ }_{122}$ Smith v. Hurd, I2 Metc. 37I (Mass. I847) ; Converse v. United Shoe Machinery Co., I85 Mass. 422, 70 N. E. 444 (I904) ; Smith v. Poor, 40 Me. 415 (I855); Allen v. Curtis, 26 Conn. 455 (1857) ; Craig v. Gregg, 83 Pa. I9 (1876); Howe v. Barney, 45 Fed. 668 (C. C. D. Ohio I\&9I); United Copper Securities Co. v. Amalgamated Copper Co., 244 U. S. 26I, 37 Sup. Ct. 509 (I917); Hubbard v. Kensington Bank, 228 App. Div. 790, 240 N. Y. Supp. 45 (1930), aff'd 254 N. Y. 587, I73 N. E. 878 (1930). In a proper case a suit commenced on the law side may be transferred to the equity side. Jacobs v. First National Bank, 35 F. (2d) 227 (W. D. La. I929), aff'd 48 F. (2) I7 (C. C. A. 5th, I93I).

izo Robinson v. Smith, 3 Paige 222 (N. Y. I832) ; Dodge v. Woolsey, 18 How. 33I (U. S. I855); Hawes v. Oakland, IO4 U. S. 450 (1882); Miner v. Belle Isle Ice Co., 93 Mich. 97, 53 N. W. 218 (I892); Gibbs v. Morgan, 9 Idaho I00, 72 Pac. 733 (Ig03).

S2 See Note (I93I) I5 MrNN. L. REv. 453. For the federal courts the requirements are embodied in Equity Rule 27,28 U. S. C. A. (I928). See comments on said rule in Ballantane, Corporations (I930) 624-625; 4 Cook, Corporations (8th ed. I923) $\$ 740$. Quaere, whether even in the federal courts the rule applies to actions brought by a stockholder to prevent the doing of an illegal act. See Dickinson v. Consolidated Traction Co., II4 Fed. 232, 242-3 (C. C. D. N. J. I902), aff'd II9 Fed. 87I (C. C. A. 3d, Ig03), certiorari denied IgI U. S. 567, 24 Sup. Ct. 840 (I903); General Inv. Co. v. Lake Shore \& M. S. Ry. Co., 250 Fed. 160. IFA (C. C. A. 6th, I918).

${ }_{220}$ The cases are legion. See 4 Cook, Corporations (8th ed. I923) \$74I; I3 Fletcher, op. cit. supra note $6, \$ 5965 ; 6$ Thompson, Corporations (3d ed. I827) $\$ 4596$. Federal Equity Rule 27 does not apply to suits against the corporation's own formal proceedings Binney v. Cumberland Ely Copper Co., I83 Fed. $65^{\circ}$ (C. C. D. Me. IgIo). If the corporation is no longer actively engaged in business, prior demand is not necessary. Crumlich's Adm'r v. Shen. Val. R. R. Co., 28 W. Va. 623 (1886); Dill v. Johnston, supra note I21; Thompson v. Stanley, supra note I2I; Tennessee M. P. \& M. Co. v. Ayers, 43 S. W. 744 (Tenn. I897). But if the corporation continues in being the demand is necessary, although the corporation is legally dissolved. Taylor v. Holmes, I27 U. S. 489,8 Sup. Ct. II92 (I888). If there are no officers or directors the demand should be made upon the stockholders or liquidating trustees. Watts v. Vanderbilt, 45 F. (2d) 968 (C. C. A. 2d, 1930). See Note (193I) 40 YALE L. J. IO8I.

${ }^{103}$ Edelstein v. Frank, 208 App. Div. 790 (N. Y. I924). But see Porter v. Healy, 244 Pa. 427, 91 At1. 428 (1914).

${ }_{17}$ O'Connor v. International Silver Co., 68 N. J. Eq. 67, 59 Atl. 321 (Ig04), aff'd 68 N. J. Eq. 680, 62 Atl. 408 (I905); Parrott v. Byers, 40 Colo. 6r4 (187r) ; Security Trust Co. v. Pritchard, Igo N. Y. Supp. 87I (I921), mod. \& aff'd 20r App. Div. I42, 194 N. Y. Supp. 486 (I922) ; Ervin v. Oregon Ry. \& Nav. Co., 62 How. Pr. 490 (N. Y. I882) ; Mitchell v. Aulander Realty Co., 169 N. C. 516,86 S. E. $35^{8}$ (I9I5) Contra: Brown v. Duluth M. \& N. Ry. Co., 53 Fed. 889 (C. C. D. Minn. I893); Hodges v. U. S. Steel Corp., 64 N. J. Eq. 90, 53 At1. 601 (1902), rev'd on other grounds, 64 N. J. Eq. 807, 54 Atl. I (Ig03). 
stock not validly issued. ${ }^{128}$ But a mere stock subscription is not. ${ }^{129}$ The owner of an equitable interest in the stock may maintain the suit even though the legal title is in another. ${ }^{130}$

When there is more than one plaintiff, the ownership of any one is sufficient for the prosecution of the action. ${ }^{131}$ If the complaining stockholder die, the suit, if it be to enforce a corporate right, does not fail, but may be continued by any other stockholder. ${ }^{132}$

One who was a stockholder at the time of the wrongs complained of may not maintain the suit after he has parted with his stock..$^{133}$

On the question whether the plaintiff must also have been a stockholder at the time of the consummation of the wrongs complained of, there is a division of authority. The federal courts, anxious to prevent collusive resort to them in preference to the local courts, insist upon this and the requirement is embodied in a rule. ${ }^{134}$ Although this rule is only one of practice and in no sense binding upon the state courts it has nevertheless influenced some of them to adopt the requirement as a matter of principle. ${ }^{135}$ The prevailing state court view is probably to the contrary. ${ }^{136}$

${ }^{128}$ McMillan v. Lamb, I66 N. Y. Supp. 656 (I9I7).

${ }^{129}$ Busey v. Hooper, $35 \mathrm{Md}$. I5 (I87r).

${ }^{100}$ Butler v. Butler Bros., 242 N. W. 701, 702, 704 (Minn. I932) ; Baum v. Sporborg, I46 App. Div. 537, I3I N. Y. Supp. 267 (IgrI); McGeary v. Brown, 23 S. D. 573. I22 N. W. 605 (1909); U. S. etc. v. O'Grady, 75 N. J. Eq. 3or, 7I Atl. I040 (I909); Chandler v. Bellanca Aircraft Corp., I62 Atl. 63 (Del. Ch. 1932). Both the pledgor, Fisher v. Patton, 34 S. W. 1096 (Mo. 1896), and the pledgee, First National Bank v. Stribling, 86 Pac. 512 (Okla. I905), have sufficient interest in the stock to sue. Contra: Whitaker v. Whitaker Iron Co., 238 Fed. 980 (N. D. W. Va. I9I6) (legatee under will). As to status of a naked trustee see Greenough v. Alabama G. S. R. Co., 64 Fed. 22 (C. C. N. D. Ala. 1894).

${ }^{231}$ Holmes v. Camp, I76 App. Div. 77I, I62 N. Y. Supp. Ior4 (I9I7).

${ }^{232}$ Spring v. Webb, 227 Fed. 48I (D. Vt. I9I5).

${ }^{233}$ Hanna v. Lyon, I79 N. Y. IO7, 7I N. E. 778 (Ig04); Zinn v. Baxter, supra note II8; Dissette v. Lawrence Pub. Co., 9 Ohio C. C. (N. S.) II\& (r9o7) ; Rafferty v. Donnelly, I97 Pa. 423, 47 At1. 202 (I900). One who was wrongfully induced to part with his stock to the defendants may maintain the suit and therein be restored to his original status. Price v. Union Iand Co., I87 Fed. 886 (C. C. A. 8th, I9II).

${ }^{234}$ Equity Rule 27 . The rule applies to an action commenced in a state court and removed to the federal court because of diversity of citizenship. Venner v. Great Northern Ry. Co., I53 Fed. 408 (S. D. N. Y. Ig07), aff'd 209 U. S. 24, 24 Sup. Ct. 28 (1908); Hitchings v. Cobalt Central Mines Co., I8g Fed. 24I (C. C. S. D. N. Y. rgro). But not where the removal is on the ground that a federal question is involved. Hand v. Kansas City So. Ry. Co., 5.5 F. (2d) $7 \mathrm{I} 2$ (S. D. N. Y. I93I). See supra note I24.

${ }^{235}$ Boldenwick v. Bullis, 40 Colo. 253, 90 Pac. 634 (Igơ) ; Home Fire Ins. Co. v. Barber, 67 Neb. 644, 93 N. W. 1024 (I903); Rankin v. Southwestern Brewery \& Ice Co., I2 N. M. 54, 73 Pac. 6I4 (I903) ; Alexander v. Searcy, 8I Ga. 536, 8 S. E. 630 (I888) (stock purchased while litigation pending, decision also strongly influenced by other factors such as laches).

${ }^{230}$ Montgomery Light \& Power Co. v. Lahey, I2r Ala. I3r, 25 So. I006 (1898) ; Just v. Idaho Canal \& Imp. Co., I6 Idaho 639, I02 Pac. 381 (Igog); City of Chicago v. Cameron, 22 Ill. App. 91 (I886), aff'd I20 Ill. 447, II N. E. 899 (I887); Forrester v. Boston \& Montana Cons. Copper Co., 21 Mont. 544, 55 Pac. 229 (I\&g) ; Winsor $\vee$. Bailey, 55 N. H. 218 (I875) ; Pollitz v. Gould, 202 N. Y. II, 94 N. E. I088 (I9II); Santen v. United States Shoe Co., 25 Ohio N. P. (N. s.) 363 (1924); Rafferty v. Donnelly, supra note I33. Where the action is based on a state statute the federal court will apply the rule governing in that state. Hand v. Kansas City So. Ry. Co., supra note I34. 
While it is frequently stated that the extent of plaintiff's stockholding in the corporation is immaterial, ${ }^{137}$ it seems that this is only true where the defendants are guilty of illegality or fraud ${ }^{138}$ and the plaintiff's right is an absolute one. If the plaintiff's financial interest in the corporation is small, that factor unmistakably influences the court, ${ }^{139}$ especially in the consideration of discretionary matters. ${ }^{140}$

Discussion of the time when the plaintiff acquired his stock and the extent of his financial interest in the corporation is frequently coupled with the more inclusive question of his motives in litigating. ${ }^{141}$ Although there are cases holding that a minority stockholder's suit may not be maintained where the plaintiff is acting not on his own behalf or on behalf of the corporation but rather at the behest of an adverse interest, ${ }^{142}$ the general rule is that the plaintiff's motive in prosecuting the suit, or in acquiring the stock is immaterial. ${ }^{143}$

${ }^{25}$ Meyerhoff v. Banker's Securities, Inc., I05 N. J. Eq. 76, I47 Atl. I05 (I929); Gordon v. Brucker, 208 I11. App. 188 (I9I7); Carver v. So. Iron \& Steel Co., 78 N. J. Eq. 8I, 78 Atl. 240 (IgIo); Stewart v. Erie \& Western Tr. Co., I7 Minn. 372 (I87I) ; Gifford v. N. J. R. R. Co., Io N. J. Eq. IfI (I854) Cf. Tanner v. Lindell Ry. Co., I8a Mo. I, 79 S. W. 155 (Ig04), as to form of relief. The principles here set forth relate also to the number of dissenters. For the purpose of federal jurisdiction, it is sufficient if the value of the corporation's right exceeds $\$ 3,000$; the value of the plaintiff's undivided interest therein is immaterial. Hutchinson Box Board \& Paper Co. v. Van Horn, 299 Fed. 424 (C. C. A. 4th, 1924). Cf. Cohn v. Cities Service Co., 45 F. (2d) 687 (C. C. A. 2d, 1930), where plaintiffs were asserting individual or "class" rights but not a corporate right. See Blume, Jurisdictional Amount in Representative Suits (193I) I5 MINN. L. REv. 501, 5I0.

${ }^{10}$ Even in fraud cases that factor is "a negative circumstance entitled to some consideration". Homer v. Crown Cork \& Seal Co., I55 Md. 66, I4I Atl. 425 (Ig28).

${ }^{250}$ Windhurst v. Central Leather Co., sippra note 90; Collins v. Martin, 248 S. W. 941 (Mo. I922); Presidio Mining Co. v. Overton, 26r Fed. 933 (C. C. A. 9th, I919); General Invest. Co. v. Bethlehem Steel Corp., 87 N. J. Eq. 235, 100 Atl. 347 (I9I7); Colby v. Equitable Trust Co., supra note I5; Callaway v. Powhatan Imp. Co., 95 Md. I77, 52 At1. 916 (Ig02); Rumney v. Detroit \& M. Cattle Co., II6 Mich. 640, 74 N. W. 1043 (I\&g8); Albers v. Merchants' Exchange, 45 Mo. App. 206 (I89I) ; Carson v. Allegany Window Glass Co., I89 Fed. 791 (C. C. D. Del. I9II).

${ }^{210}$ General Inv. Co. v. Lake Shore \& M. S. Ry. Co., supra note 124; Johnson v. United Railways, 227 Mo. 423, I27 S. W. 63 (19ro); Ryan v. Williams, I00 Fed. I72 (C. C. E. D. Va. 1900); Becker v. Hoke, 80 Fed. 973 (C. C. A. 7 th, I897); Greenough v. Alabama G. S. R. Co., supro note 130; Aldrich v. Union Bag \& Paper Co., 8I N. J. Eq. 244, 87 At1. 65 (I9I3). In the last cited case a receiver pendente lite was denied even though the directors had no financial interest in the corporation.

in For a collection of cases Note (I930) 67 A. L. R. I470.

${ }^{112}$ Forrest v. Manchester, Sheff. \& I. Ry. Co., 4 DeG. F. \& J. I26 (Eng. I86I) ; Beshoar v. Chappeile, 6 Colo. App. 323, 40 Pac. 244 (I895); Waterbury v. Merchants Union Exp. Co., 50 Barb. I57 (N. Y. I867); Belmont v. Erie Ry. Co., 52 Barb. 637 (N. Y. I869). Cf. Southwestern Portland Cement Co. v. Latta \& Happer, I93 S. W. III5 (Tex. Civ. App. I9I7). See also Sparhawk v. Union Passenger Ry. Co., 54 Pa. 40I, 452 (I867).

${ }_{143}$ Johnson v. King-Richardson Co., 36 F. (2d) 675 (C. C. A. Ist, 1930); Central R. R. Co. v. Collins, 40 Ga. 582 ( 1869 ); Macon Gas Co. v. Richter, I43 Ga. 397, 85 S. E. II2 (IgI3) ; Hodge v. U. S. Steel Corp., 64 N. J. Eq. III, 53 Atl. 553 (I902); Bull v. International Power Co., 84 N. J. 'Eq. 6, 92 Atl. 796 (IgI4), af'd 85 N. J. Eq. 206, 96 Atl. 364 (IgI5) ; Ramsey v. Gould, 57 Barb. 398 (N. Y. I87o) ; Colman v. Eastern Counties Ry. Co., Io Beav. I (Eng. I846) ; Seaton v. Grant, L. R. 2 Ch. App. 459 (I867) 6 This principle does not prevent inquiry to ascertain whether the plaintiff is the real party in interest. MacGinniss v. Boston \& Montana C. C. \& S. M. Co., 29 Mont. 428, 75 Pac. 89 (1904). Plaintiff's motive may influence the form of relief accorded him. Kingman v. Rome, W. \& O. R. R. Co., 30 Hun 73 (N. Y. I883) ; Lewisohn Bros. v. Anaconda Copper M. Co., 26 Misc. 613, 56 N. Y. Supp. 807 ( 1899 ); and may be considered on questions of credibility, Continental Securities 
Bars. $^{144}$

Even if there be a valid corporate right of action the assertion of it by a particular stockholder may be barred by his own prior conduct. Logically this position is in apparent disregard of the basic nature of the derivative suit, namely, that it is brought to redress a corporate wrong and not for the individual benefit of the stockholder who happens to be plaintiff. From this notion it ought perhaps, in strict logic to follow that the suit can only be barred by action on the part of the corporation, but such is not the law. Courts of equity have refused to permit the assertion of corporate rights by a stockholder who was personally estopped, ${ }^{145}$ who had knowingly accepted benefits under the transaction sought to be attacked, ${ }^{146}$ who had ratifred or acquiesced in the transaction, ${ }^{147}$ or who had otherwise waived his right to complain, ${ }^{148}$ or was guilty of laches. ${ }^{149}$

Freedom from these bars need not be pleaded by the plaintiff. ${ }^{150}$ They constitute affirmative defenses which must be pleaded by the defendants unless they sufficiently appear upon the face of the complaint, ${ }^{151}$ although a court may, on its own motion, take cognizance thereof. ${ }^{152}$ Of course, their

Co. v. Belmont, 83 Misc. 340, 144 N. Y. Supp. 8oI (I9I3), aff'd I68 App. Div. 483, I54 N. Y. Supp. 54 (I9I5), aff'd 222 N. Y. 673, II9 N. E. IO36 (I9I8). We are not here concerned with the special rules applicable to proceedings to obtain access to corporate books and records. See 5 FLETCHER, op. cit. suppra note 6, c. I8.

${ }^{24}$ The author uses the word "bars" rather than "defenses" to distinguish between matters which go only to the right of the particular plaintiff to complain (bars) and matters which go to defeat the claim itself (defenses).

${ }^{265}$ Pollitz v. Wabash R. R. Co., 207 N. Y. II3, I00 N. E. 72I (I92I) ; Post v. Beacon Vacuum Pump \& E. Co., 84 Fed. 37I (C. C. A. Ist, 1898); Klein v. Independent Brewing Assn., 23I I11. 594, 83 N. E. 434 (1908). See also Harris v. Pearsall, II6 Misc. 366, Iga N. Y. Supp. 6I (Ig2I).

2i6 Wormser v. Metropolitan Street Ry. Co., I84 N. Y. 83, 76 N. E. 1036 (1906). See also Harris v. Pearsall, supra note 145.

${ }_{217}$ Pollitz v. Wabash R. R. Co., supra note 445 ; Burden v. Burden, supra note 36 ; Venner v. N. Y. C. \& H. R R Co, I77 App. Div. 296, I64 N. Y. Supp. 626 (I9I7), aff'd 226 N. Y. 583, r23 N. E. 893 (I919) ; Johnson v. King-Richardson Co., supra note I43: Pigeon River Ry. Co. v. Champion Fibre Co., 280 Fed. 557 (C. C. A. 4th, I922); Watt's Appeal, $78 \mathrm{~Pa}$. 370 (I875). Contra: Fitzgerald v. Fitzgerald \& Mallory Const. Co., 4I Neb. 374, 58 N. W. 858 (1894) ; Roth v. Robertson, 64 Misc. 343, II8 N. Y. Supp. 35I (Ig09) (as to acts mala prohibita or mala in se). See also Harris v. Pearsall, supra note 145 . When a trustee seeks to bar his cestui by "ratification", it must appear that he made full disclosure, not only of the facts, but also of the cestui's legal rights. See Garrett v. Reid-Cashion Land \& Cattle Co., 34 Ariz. 245, 270 Pac. I044 (I928).

14 Johnson v. King-Richardson Co., supra note I43.

${ }^{103}$ Kessler v. Ensley Co., I23 Fed. 546 (C. C. N. D. Ala. 1903) ; Venner v. N. Y. C. \& H. R. R. Co., supra note I47; Stephany v. Marsden, 75 N. J. Eq. 90, 7 I Atl. 598 (Ig08), aff'd 76 N. J. Eq. 6II, 75 Atl. 899 (Ig00); Ashhurst's Appeal, 60 Pa. 290 (I869): As to what constitutes laches see Cahall v. Burbage, II9 Atl. 574 (Del. Ch. I922). At times the application of the doctrine of laches is made to depend upon whether the relief sought is a matter of right or of discretion. See Pollitz v. Wabash R. R. Co., supra note I45; American Seating Co. v. Bullard, 290 Fed. 896. (C. C. A. 6th, I923).

${ }_{150}$ Horn Silver Mining Co. v. Ryan, 42 Minn. I96, 44 N. W. 56 (1889); Continental Securities Co. v. Belmont, 206 N. Y. 7, I3, 99 N. E. I38, I40 (IgIz).

${ }_{101}$ Sabre v. United Traction \& Elec. Co., I56 Fed. 79 (C. C. D. R. I. I907). The burden of proof is likewise upon the defendants. Mason v. Carrothers, I05 Me. 392, 408, 74 Atl. ro3o, I037 (rgog).

${ }^{x 2}$ Hall v. Nash, 33 Colo. 500, 81 ${ }^{\circ}$ Pac. 249 (I905). See also Calivado Col. Co. v. Hays, IIg Fed. 202 (C. C. W. D. Pa. 1902). 
existence bars only the particular plaintiff against whom they operate and does not affect other stockholders even if they be co-plaintiffs. ${ }^{153}$

As the suit may be barred by the personal disabilities of the plaintiff notwithstanding its representative character so the individual plaintiff may, until others intervene, ${ }^{154}$ deal with it as if it were his own, at least until decree entered, and may discontinue it. ${ }^{155}$

In accordance with the idea that the purchaser of stock acquires all the rights of the vendor, including the right to attack prior transactions, it is held that where a prior owner of the stock has participated in or consented to the alleged improprieties, no subsequent owner of that stock may attack them. ${ }^{156}$ Under present marketing conditions this principle has an element of unfairness in it, if we accept the view that a stockholder should be permitted to sue for prior wrongs, because it is most rare for a purchaser to have any direct contact with his transferor, or any knowledge of his actions as stockholder. Indeed, the purchaser generally neither knows nor cares whose stock he is purchasing. ${ }^{157}$

${ }^{163}$ Endicott v. Marvel, supra note IIg.

wes Except when denied because of undue delay, McArdell v. Olcott, 62 App. Div. 127, 70 N. Y. Supp. 930 (I90I) ; Streuber's Appeal, $229 \mathrm{~Pa}$. 184, 78 Atl. I06 (Igro), the right of intervention is freely granted. Southern Pacific Co. v. Bogart, supra note 29 . Indeed, no formal order is necessary. Coltrane v. Templeton, I06 Fed. 370 (C. C. A. 4th, I90I). Cf. Hay v. Brookfield, I60 App. Div. 277, I 45 N. Y. Supp. 543 (Igr4), denying leave to a majority stockholder to intervene as a party defendant. Where the plaintiff is acting for the controlling interests, other stockholders will be permitted to intervene. Thayer v. Kinder, 45 Ind. App. III, 90 N. E. 323 (I909). For a case of intervention by a holder of non-voting preferred stock, see Hamlin v. Toledo, etc. R. R. Co., 78 Fed. 664 (C. C. A. 6th, 1897). The status of the intervenor may cure defects in jurisdiction. Grant v. Greene Cons. Copper Co., I69 App. Div. 206, I54 N. Y. Supp. 596 (I915), aff'd 223 N. Y. 655, IIg N. E. I053 (1915), but will not destroy or change jurisdiction as originally fixed. Wichita $R$. $R$. \& T. Co. v. Public Utilities Commission, 260 U. S. 48, 43 Sup. Ct. 5 I (Ig22); Thouron v. East Tenn. V. \& G. Ry. Co., 38 Fed. 673 (C. C. E. D. Tenn. 1889). So too, if the intervenor is a stockholder, it may save the action even though the original plaintiff is not. Hanna v. Lyon, supra note I33. After intervention the original plaintiff may not abandon or discontinue the suit, and upon his failure to prosecute it the intervenor may. Manning v. Mercantile Trust Co., 37 Misc. 2I5, 75 N. Y. Supp. I68 (I902) ; Culver Lumber Co. v. Culver, 81 Ark. 102, 99 S. W. 39I (I906); McAlpin v. Universal Tobacco Co., 57 Atl. 4 I8 (N. J. I904). Intervenors may be allowed compensation for their attorneys. Goodman v. Von Cotzhausen, I7I Wis. 35I, I77 N. W. 618 (1920).

${ }_{15}$ Brinckerhoff v. Bostwick, 99 N. Y. I85, I N. E. 663 (I885) ; Bernheimer v. Wallace, I $86 \mathrm{Ky} .450,2 \mathrm{I} 7 \mathrm{~S}$. W. $9 \mathrm{I} 6$ (I920). The last cited case contains a discussion of the court's duty to protect unrepresented stockholders. The phrase "as if it were his own" is too broad because it entirely overlooks the essential fiduciary character of the plaintiff. See National Power \& Paper Co. v. Rossman, I22 Minn. 355, I42 N. W. 818 (1913); Whitten v. Dabney, I7I Cal. 62I, I54 Pac. 3I2 (I9I5). The effect of his acts upon others will be considered later.

in Babcock v. Farwell, 245 Ill. 14, 9r N. E. 683 (1910) ; Home Fire Ins. Co. v. Barber, supra note $\mathrm{T} 35$. This is an affirmative defense to be pleaded by the defendants. Continental Securities Co. v. Belmont, supra note I50. Contra: Trimble v. Amer. Sugar Ref. Co., supra note 36.

${ }^{207}$ In cases against promoters (reference to which we are avoiding in this paper) an attempt is frequently made to escape from the consequences of this rule by treating the initial issuance to the promoters, in those cases where they immediately return or make available to the corporation stock for public sale, as a mere subterfuge. California-Calaveras Min. Co. v. Walls, 170 Cal. 285, I49 Pac. 595 (ror5); Mason v. Carrothers, stipra note I5I; Fred. Macey Co. v. Macey, I43 Mich. I38, 106 N. W. 722 (1906); American Forging Co. v. Wiley, 206 Mich. 664, I73 N. W. 515 (I9I9); Santen v. U. S. Shoe Co., supra note I36; Anderson v. Jolnnson, 45 R. I. I7, II9 Atl. 642 (1923); Pittsburgh Mining Co. v. Spooner, 74 Wis. 307 , 42 N. W. 259 ( 1889 ); Pietsch v. Milbrath, 123 Wis. 647, ror N. W. 388 (1904). See Berle, Bankers' and Promoters' Stock Profits (Ig29) 42 HARv. L. Rev. 748, 756-759. 
Necessary Defendants.

The corporation is a necessary party to the suit ${ }^{158}$ but neither all the directors nor even all the alleged wrongdoers are indispensible parties. ${ }^{159}$

Venue.

Homage is still paid to the general rule that "courts will not take jurisdiction of the internal affairs of a foreign corporation, or, in the exercise of visitorial powers, interfere with, supervise, administer, or direct the management of such a corporation", ${ }^{160}$ and where convenient, in deference to this principle, it is best to sue in the state of domicile. ${ }^{161}$ The principle can not, however, be deemed an absolute bar to the maintenance of such suits elsewhere. In the first place, there is no uniformity in the decisions as to what constitute "internal affairs". Secondly, a distinction is frequently drawn between "controlling" management and "redressing" mismanagement. Finally, and of prime importance, the rule has come to be recognized as not one of jurisdictional powers but only as one of policy and discretion. The result is that "foreign" courts do exercise their jurisdiction in a "proper" case. Broadly speaking, more and more weight is being given to the actual facts of the corporation's business activities as distinguished from its merely formal domicile. ${ }^{102}$ A court which acquires jurisdiction of the necessary defendants will decline to act, if satisfied that a grievance exists, only in cases where "considerations of convenience, efficiency and justice point to the

${ }^{158}$ City of Davenport v. Dows, I8 Wall. 626 (U. S. I874) ; Porter v. Sabin, I49 U. S. 473, I3 Sup. Ct. 1008 (I892) (receiver of insolvent corporation should be joined); Lawrence v. Southern Pacific Co., I80 Fed. 822 (C. C. E. D. N. Y. I9ro) appeal dismissed sub nom. Bogart v. So. Pac. R. R. Co., 228 U. S. I37, 33 Sup. Ct. 497 (I9r3) ; Hyams v. Old Dominion Co., 204 Fed. 68I (D. Me. I9I3), aff'd 209 Fed. 808 (C. C. A. Ist, I9I3); McNeely v. E. I. DuPont deNemours Powder Co., 263 Fed. 252 (D. Del. Ig20); Busch v. Mary A. Riddle Co., 283 Fed. 443 (D. Del. I922) ; Beach v. Cooper, 72 Cal. 99, I3 Pac. I6r (I887); Von Arnim v. American Tube Works, I88 Mass. 515, 74 N. E. 680 (I905); McMillan v. Miller, I77 Mich. 5II, I43 N. W. 63I (I9I3) ; Robinson v. Smith, stupra note I23; Brady v. Meenan, 204 App. Div. 390, I98 N. Y. Supp. I77 (I923). Cf. Toledo Traction, Light \& Power Co. v. Smith, 205 Fed. 643 (N. D. Ohio I913). With respect to dissolved corporations see (r93I) 40 YALE L. J. 108I; Hamm v. Christian Herald Corporation, 236 App. Div. 639,260 N. Y. Supp. 743 (I932).

${ }^{159}$ Eldred v. American Palace-Car Co., 99 Fed. 168 (C. C. D. N. J. 1900) ; Wickersham v. Crittenden, 93 Cal. I7, 28 Pac. 788 (I892); Von Arnim v. American Tube Works, supra note 158; Baker v. Baker, I22 Misc. 757, 204 N. Y. Supp. II (1924), aff'd 212 App. Div. 850 (1924). Cf. Harden v. Eastern States Pub. Service Co., I4 Del. Ch. 156, I22 Atl. 705 (I923) (corporation sole defendant). As to the propriety of their joinder see Berwind $v$. Van Horne, ro4 Fed. 58r (C. C. S. D. N. Y. 1900); Schell v. Alston MIfg. Co., r49 Fed. 439 (C. C. N. D. I11. Ig06); Gray v. Fuller, I7 App. Div. 29, 44 N. Y. Supp. 883 (I897); McCrea v. McClenahan, Ir4 App. Div. 70, 99 N. Y. Supp. 689 (I906) (as to stockholders).

${ }^{100}$ The cases are annotated in Note (r922) I8 A. L. R. I383 and discussed in Note (I929)

29 Col. L. Rev. 968 . See Rogers v. Guaranty Trust Co., sipra note 69.

${ }^{201}$ As to the jurisdiction of the federal court in such state see Doctor v. Harrington, Ig6 U. S. 579, 25 Sup. Ct. 355 (Ig05); Mills v. City of Chicago, I43 Fed. 430 (C. C. N. D. Ill. I906), aff'd 204 U. S. 32I, 27 Sup. Ct. 286 (I907) ; Dodge v. Woolsey, supra note I23; Consumers' Gas Trust Co. v. Quinby, 137 Fed. 882 (C. C. A. 7th, 1905) ; New Albany Waterworks v. Louisville Banking Co., I22 Fed. 776 (C. C. A. 7th, I903); Barnes v. Kornegay, 62 Fed. 67 I (C. C. W. D. N. C. I894).

${ }^{202}$ See dissent of Mr. Justice Stone in Rogers v. Guaranty Trust Co., supra note 69. 
courts of the state of the domicile as appropriate tribunals for the determination of the particular case". ${ }^{163}$

Even if jurisdiction is entertained in a foreign state, the law of the forum will not necessarily govern; on certain questions the law of the domicile of the corporation will control, ${ }^{164}$ and on others the law of the place of performance of the acts involved. ${ }^{165}$

Form of Relief. ${ }^{160}$

A cause of action being established, it may be assumed that the court will "find the means of enforcing its decree" and that its powers will prove "as extensive as the exigencies of the case". ${ }^{167}$ There is the whole array of equitable decrees to choose from and each case will be given "such remedy as its circumstances may require". ${ }^{168}$ In making its decree the court is not circumscribed by any arbitrary designations of the precise form of relief; "it may vary, qualify, restrain, and modify the remedy it applies so as to do equity".109

When the action is strictly derivative the plaintiff can be granted only such relief as could be granted the corporation if it were plaintiff. ${ }^{170}$ And conversely, in such a suit the plaintiff cannot be compelled to accept less than the corporation would be entitled to receive. ${ }^{171}$

The most commonly sought forms of redress are injunctions against threatened acts ${ }^{172}$ and an accounting for past wrongs. ${ }^{173}$ Occasionally re-

${ }_{103}$ Rogers v. Guaranty Trust Co., supra note 69; Note (I93I) 44 HARv. L. Rev. 437-439.

${ }^{106}$ Voorhees v. Mason, 243 III. 256, 9 I N. E. 1056 (I9ro); Orton v. Edson Red. Mach. Co., 5 Ohio C. C. (N. S.) 540, aff'd 75 Ohio St. 580,80 N. E. II26 (I905). See also Rogers v. Guaranty Trust Co., sutpra note 69 , where the refusal of a "foreign" court to exercise jurisdiction because the case involved questions of law of the state of domicile was sustained. Cf. Hamm v. Christian Herald Corp., supra note 158 .

${ }^{100}$ Old Dominion Copper M. \& S. Co. v. Bigelow, 203 Mass. I59, I73-I74, 89 N. E. 193, 200 (1909).

${ }^{103}$ In this section we shall not attempt to be exhaustive; reference is made to the standard texts on equity pleading and practice. All the cases noted in this paper illustrate the forms of relief available. In the next succeeding notes we shall merely refer to a few more illustrative cases.

${ }^{107}$ Wickersham v. Crittenden, supra note I59.

${ }^{19}$ Hyams v. Calumet \& Hecla Min. Co., supra note 30, at 544.

${ }^{10}$ Jones v. Missouri-Edison Electric Co, supra note 15 , at 78r. But a court will not work up a case out of the facts to give the plaintiff relief which he does not ask. Tanner $v$. Lindell Ry. Co., supra note 137 . We have already noted how the form of relief may be affected by the plaintiff's bad faith, supra note I43, or by his laches, supra note I49.

${ }^{200}$ Collins v. Penn-Wyoming Copper' Co., 203 Fed. 726 (D. Wyo. I9I2) ; Viley v, Wall, I59 La. 627, 105 So. 794 (I925).

${ }^{172}$ E. g., money damages for his individual loss. Morris v. Elyton Land Co., I25 Ala. 263, 28 So. 51 ( I899). Cf. Binney v. Cumberland Ely Copper Co., supra note 125, and Pennsylvania decisions cited supra note 84 .

${ }^{172}$ Smith v. Chase Baker Piano Mfg. Co., supra note I2; Davidson v. American Blower Co., 243 Fed. I67 (C. C. A. 2d, x917); Cuppy v. Ward, 187 App. Div. 625, 176 N. Y. Supp. 233 (IgI9), aff'd 227 N. Y. 603, I25 N. E. 915 (IgIg); Schwab v. Potter Co., I94 N. Y. 409, 87 N. E. 670 (Ig09), aff'g 120 App. Div. 36, I13 N. Y. Supp. 439 (Ig09).

${ }_{x 73}$ Sage v. Culver, supra note 33 ; Brock v. Poor, 216 N. Y. 38 \%, III N. E. 229 (I9I5); Major v. American Malt \& Grain Co., supra note III: Fredendall v. Schrader, 45 Cal. App. 719, I88 Pac. 580 (I920) ; Barr v. N. Y. L. E. \& W. R. R. Co., supra note I8. 
dress against past acts is to be had by way of rescission ${ }^{174}$ and future correct conduct is enforced by a decree of specific performance. ${ }^{175}$

The forms of relief most peculiar to corporate litigation, and the most drastic available, are the appointment of a receiver and its compulsory dissolution.

The power of a court of equity, independent of statute, to appoint a receiver of a solvent, going concern can no longer be doubted. ${ }^{176}$ But it is still regarded as an extreme remedy to be granted only where clearly necessary ${ }^{177}$ and where other forms of equitable relief, such as injunction, are insufficient. ${ }^{178}$ The appointment of a receiver may not be the sole or primary purpose of the suit, it must be merely provisional to some other ultimate relief. ${ }^{179}$ Where necessary, a receiver will be appointed if the directors are guilty of fraud and mismanagement. ${ }^{180}$ But the charge of "mismanagement" must be based upon something more than differences of opinion as to business policies or methods. ${ }^{181}$ Not even past misconduct will necessarily require the appointment of a receiver; the misconduct of the directors must be of such a character as to satisfy the court of their unfitness and of the

${ }^{134}$ Carson v. Allegany Window Glass Co., supra note I39; Binney v. Cumberland Ely Copper Co., supra note I25; Metcalf v. American School Furn. Co., I22 Fed. II5 (C. C. W. D. N. Y. I903); Morris v. Elyton Land Co., supra note 17I; Macgill v. Macgill, I35 Md. 384 , I09 Atl. 72 (I9I9); Kidd v. N. H. Traction Co., 72 N. H. 273, 56 Atl. 465 (Ig03). The right to rescission is frequently affected by the intervening rights of innocent persons and rescission is frequently accompanied with an accounting against the wrongdoers. Such accounting is at times given in lieu of rescission. $C f$. Johnson v. United Rys., supra note I40.

${ }_{176}$ Presidio Mining Co. v. Overton, 270 Fed. 388 (C. C. A. 9th, I92I), certiorari denied 256 U. S. 694, 4I Sup. Ct. 535 (I92I) (compelling a director to convey property to the corporation).

${ }_{176}$ Burwrite Coal Briquette Co. v. Riggs, 274 U. S. 208, 47 Sup. Ct. 576 (1927) ; Columbia N. S. D. Co. v. Washed Bar S. D. Co., I36 Fed. 7Io (C. C. E. D. Pa. Ig05) ; Piza v. Butler, go Hun 254, $35 \mathrm{~N}$. Y. Supp. 72I (I895)! (statutory action); Schipper Bros. C. M. Co. v. Economy Domestic C. Co., 277 Pa. 356, I21 Atl. I93 (I923); Culver Lumber \& Mf́fg. Co. v. Culver, supra note I54 (on application of majority stockholder).

Irt Shera v. Carbon Steel Co., 245 Fed. 589 (D. W. Va. 19r7); Collins v. Williamson, 229 Fed. 59 (C. C. A. 6th, IgI5); Thoroughgood v. Georgetown Water Co., 9 Del. Ch. 84, 77 Atl. 720 (1910); Welcke v. Trageser, 131 App. Div. 731, II6 N. Y. Supp. 166 (1909); Thalmann v. Hoffman House, 27 Misc. 140, 58 N. Y. Supp. 227 (1899). There is perhaps a growing liberality as to what constitutes a proper case for the appointment of a receiver. For a discussion of judicial trends as to this power see Gibbs v. Morgan, supra note I23; Brent v. B. E. Brister Sawmill Co., I03 Miss. 876, 60 So. Ior8 (1913); Goodman v. Von Cotzhausen, supra note I54; Bowen v. Bowen-Romer Flour Mills Corp., Ir4 Kan. 95, 2I7 Pac. 301 (1923) ; Berkshire Pet. Co. v. Moore, 268 S. W. 484 (Tex. Civ. App. I924). But see Tachna v. Pressed Steel Car Co., Irz N. J. Eq. 4II, I64 Atl. 4I3 (I933) (calling a halt in a creditor's suit).

${ }_{1 r}$ Lowe v. Pioneer Threshing Co., supra note 60; New Albany. Water Works v. Louisville Banking Co., supra note I6I ; United Electric Sec. Co. v. Louisiana Elec. Co., 68 Fed. 673 (C. C. E. D. La. 1895); Moore v. Associated P. \& R. Corp., I4 Del. Ch. 97, 121 Atl. 655 (I923); Smallwood v. Smith, I97 App. Div. 533, I89 N. Y. Supp. 427 (I921).

Ir Myers v. Occidental Oil Corp., 288 Fed. 997 (D. Del. I923); Zuber v. Micmac Gold M. Co., I80 Fed. 625 (C. C. D. Me. Igro); Edwards v. Bay State Gas Co., 9r Fed. 942 (C. C. D. Del. I898).

${ }_{180}$ Aiken v. Colorado River I. Co., 72 Fed. 59 I (C. C. S. D. Colo. I896); Hallenborg v. Greene, 66 App. Div. 590,73 N. Y. Supp. 403 (I90I); Jacobus v. Diamond Soda Water Mfg. Co.. 94 App. Div. 366.88 N. $\dot{Y}$. Supp. 302 (I904).

isi Hunt v. American Grocery Co., 80 Fed. 70 (C. C. D. N. J. 1897) ; Carson v. Allegany Window Glass Co., supra note I39; Thomas v. East End Opera House Co., 30 Pitts. L. J. (N. S.) 230 ( 1899 ). 
probability of further loss or injuries to the corporation and stockholders. ${ }^{182}$ Serious dissension in the corporation may also move a court to appoint a receiver. ${ }^{183}$

We have already noted that a court of equity may at the suit of minority stockholders prevent the dissolution of the corporation. ${ }^{184}$ Will it ever compel a dissolution? There is considerable language in the books to the effect that, exclusive of statute, a court of equity has no power to compel a dissolution of the corporation. ${ }^{185}$ If we distinguish between the compulsory surrender of its corporate franchise and the winding up of its business as a going concern, ${ }^{186}$ it seems that, at least with respect to the latter, the court has the power, ${ }^{187}$ but, recognizing the gravity of its use, uses it sparingly and only when absolutely necessary for the adequate protection of the minority. ${ }^{188}$

\section{Effect of Decree in One Suit on Other Stockholders.}

Where the suit is not merely a personal one ${ }^{189}$ but is one on behalf of the corporation, a judgment obtained on the merits in one stockholder's suit binds all stockholders. ${ }^{190}$ This result does not follow if the first judgment

152 Carson v. Allegany Window Glass Co., supra note I39.

${ }^{203}$ Ellis v. Penn Beef Co., 9 Del. Ch. 213, 80 Atl. $666^{\circ}$ (IgII) ; Powers v. Blue Grass Bldg. Co., 86 Fed. 705 (C. C. D. Ky. I898) ; Schipper Bros. Coal M. Co. v. Economy Domestic Coal Co., supra note 176 . In most cases where a receiver is appointed on the ground of dissension there is "a more or less equal division between the contending factions". Note (I926) 43 A. L. R. 260; Hlawati v. Maeder-Hlawatí Co., supra note 37.

Isi Supra note 9.5 .

15 Republican Mountain S. Mines v. Brown, 58 Fed. 644 (C. C. A. 8th, I893) ; Sidway v. Missouri Land \& L. S. Co., Ior Fed. 48I (C. C. S. D. Mo. I900) ; Taylor v. Decatur Mineral Land Co., II2 Fed. 449 (C. C. N. D. Ala. I90I), aff'd Ir5 Fed. ro22 (C. C. A. 5th, Ig02); Pearce v. Sutherland, 164 Fed. 609 (C. C. A 9th, 1908) ; Myers v Occidental Oil Corp., supra note 179; Benedict v. Columbus Const. Co., 49 N. J. Eq. 23, 23 Atl. 485 (I8gr) ; Denike v. N. Y. R. L. \& C. Co., 80 N. Y. 599 (I880); Hlawati v. Maeder-Hlawati Co., supra note 37. Cf. Schipper Bros. C. M. Co. v. Economy D. C., supra note 176 .

${ }_{183}$ Sellman v. German Union Fire Ins. Co., I84 Fed. 977 (C. C. D. Del. 1909). See Note (I93I) 44 HARV. L. REv. 437, 440.

${ }_{157}$ Miner v. Belle Isle Ice Co., supra note I23 (close corporation, dissension, fraud, mismanagement); Goodman v. Von Cotzhausen, supra note I54 (same situation and emphasis upon lack of good business qualities in controlling stockholders); Arento v. Blackwell's D. T. Co., ror Fed. 338 (C. C. E. D. N. C. 1900), 108 Fed. In58 (C. C. A. 4th, I901) (at the suit of majority). In Riley v. Callahan Mining Co., 28 Idaho 525, I55 Pac. 665 (I9I6), the same result was substantially obtained by compelling the corporation which had ceased to mine but had become a mere holding company to distribute its stock holdings. See also Note (I93I) 44 HARV. L. REv. 437.

${ }_{189}$ Presidio Mining Co. v. Overton, supra note 175 ; Brictson Mfg. Co. v. Close, 280 Fed. 297 (C. C. A. 8th, I922); Sellman v. German Union Fire Ins. Co., supra note I86; Bixler v. Summerfield, 2ro I11. 66, 70 N. E. I059 (1904).

${ }_{1 \Re 9}$ Harris v. Pearsall, supra note I45; Colgan v. Fink, 167 App. Div. 718 , 153 N. Y. Supp. 239 (I9I5). In Jackson v. Gardiner, 200 Fed. II3 (C. C. A. Ist, I9I2), the importance of it appearing that the prior suit was on behalf of all who might join therein was stressed. $C f$. Roberts v. Kennedy, 13 Del. Ch. I33, II6 Atl. 253 (rg22). For "class" suits, see 34 C. J. 1002, § I422.

iso Dana v. Morgan, 232 Fed. 85 (C. C. A. 2d, I9I6) ; Willoughby v. Chicago Junction Rys. Co., supra note 67; Goodbody v. Delaney, 80 N. J. Eq. 417, 83 At1. 988 (I912) ; Grant v. Greene Cons. Copper Co., supra note I54; Hearst v. Putnam Mining Co., 28 Utah I84, 77 Pac. 753 (Ig04); Corey v. Independent Ice Co., I06 Me. 485, 76 Atl. 930 (Igro); Hochman v. Mortgage Finance Corp., $289 \mathrm{~Pa}$. 260, I37 Atl. 252 (I927). Cf. Southern Pacific Co. v. Bogert, supra note 29. The same principle, of course, applies where the corporation itself acted in the first suit. Alexander v. Donohoe, I43 N. Y. 203, 38 N. E. 263 (I894). 
was obtained by fraud or collusion, ${ }^{191}$ or, it would seem, if it were entered merely on consent of the parties thereto without an actual bona fide litigation having been presented to the court for adjudication. ${ }^{192}$

Costs and Allowances.

For the purpose of receiving and paying costs the plaintiff is regarded as an individual plaintiff. ${ }^{193}$ A successful plaintiff who sues on behalf of his corporation is entitled to an allowance for his expenditures, including counsel fees, out of the corporate funds, ${ }^{194}$ but not against the individual defendants except pursuant to statute. ${ }^{195}$ The plaintiff is not entitled to such an allowance where he has recovered only a personal judgment. ${ }^{196}$ Generally an allowance is made only where there is an actual recovery by the corporation or a fund is brought into court for distribution. ${ }^{197}$

\section{CONCLUSION}

No accumulation of dicta can conceal the fact that intra-corporate controversies have been dropped into the wide lap of the chancellor-for better or for worse, depending upon his economic statesmanship. Easy familiarity with the language of the books will not suffice. His powers are wide; his arsenal adequate. And the measure of his success will not be the logical con-

${ }^{191}$ Willoughby v. Chicago Junction Rys. Co., supra note 67 ; Beers v. Denver \& R. G. W. R. Co., 286 Fied. 886 (C. C. A. 8th, I923); Levy v. Equitable Trust Co., 27 I Fed. 49 (C. C. A. 8th, I92I) ; Gund v. Bullard, 73 Nebr. 547, 103 N. W. 309 (I905) (applying the exception where in the first suit an issue was not fully or fairly presented).

${ }_{102}$ Metropolitan Elevated R. R. Co. v. Manhattan Elevated R. R. Co., II Daly 373 (N. Y. 1884) ; Cutter v. Arlington Casket Co., 255 Mass. 52, I5I N. E. I67 (1926); Spaulding v. North Milwaukee T. S. Co., I06. Wis. 48I, 8I N. W. 1064 (I900). Contra: Zeitinger v. Hargardine-McKittriep Dry Goods Co., 309 Mo. 433, 274 S. W. 789 (I925); Kaufman v. Annuity Realty Co., 30I Mo. 638, 256 S. W. 792 (I923). Ralph v. Annuity Realty Co., 325 Mo. 4ro, 28 S. W. (2d) 662 ( (I930). By analogy: Jenkins v. Robertson, L. R. I Scotch \& Div. App. Cas. II7 (I867); Kelley v. Town of Milan, I27 U. S. 139, 8 Sup. Ct. Iror (I888); Union Bank v. Commissioners, II9 N. C. 214, 25 S. E. 966 (I896). See also supra note I55.

${ }_{103}$ Edwards v. Bay State Gas Co., supra note 179. An intervenor is not liable for costs accrued before his intervention. Whitten v. Dabney, supra note 155 .

${ }_{200}$ Meeker v. Winthrop Iron Co., supra note 2; Beaudette v. Graham, 267 Mass. 7, 165 N. E. 67 I (I929); Guay v. Holland System Hull Co., 244 Mass. 240, I38 N. E. 557 (I923); cases cited I3 FLETCHER, op. cit. supra note $6, \$ 6045$. But his agreement with counsel as to amount is not necessarily binding upon the corporation or the court. Hutchinson Box Board \& Paper Co. v. Van Horn, supra note 137; Saut v. Perronville Shingle Co., I79 Mich. 42, I46 N. W. 212 (I9r4). The same rules apply to an intervenor. Goodman v. Von Cotzhausen, supra note 154. See Hartman v. Oatman Gold M. \& M. Co., 22 Ariz. 476, 198 Pac. $7 \mathrm{I} 7$ (I92I), for an independent suit by a stockholder against corporation to recover expenditures. For cases involving the right of directors to employ counsel in minority stockholder's suits see Cory v. Independent Ice Co., supra note I92; McConnell v. Combination M. \& M. Co., 3I Mont. 563, 79 Pac. 248 (Ig05) ; Godley! v. Crandall \& Godley Co., supra note 44; Kannenberg v. Evangelical Creed Cong., I46 Wis. 6I0, I3I N. W. 353 (I9II).

${ }_{100}$ Kilby v. Movius L. \& L. Co., 55 N. D. 830,215 N. W. 284 (I927).

${ }^{100}$ Boothe v. Summit Coal M. Co., 72 Wash. 679, I3I Pac. 252 (IgI3) ; Joyce v. Congdon, II4 Wash. 239, I95 Pac. 29 (I92I).

${ }_{107}$ Alexander v. Atlantic \& W. P. R. R. Co., Ir3 Ga. 193, 38 S. E. 772 (Ig0I) (attorneys' fees not allowed in action resulting in injunction against ultra vires acts); Burley Tobacco Co. v. Vest, $165 \mathrm{Ky} .762$, I78 S. W. I 102 (1915) (allowances denied where plaintiff established invalidity of an election of directors). Cf. Forrester \& MacGinniss v. Boston \& M. C. C. \& S. M. Co., 29 Mont. 397, 76 Pac. 2 II (r904). It would seem that a court may properly consider non-tangible benefits resulting to the corporation even if not immediately serving to increase its physical assets. 
sistency of his opinions but the wisdom and justice he brings into the realm of economics from the field of law. ${ }^{198}$

In the immediate future, it would seem, more attention must be given to the increasing separation that exists between ownership and control. In the past, decisions have been strongly influenced by the fact that the majority which controlled also had the largest financial interest in the corporation. ${ }^{199}$ This is frequently no longer true, ${ }^{200}$ but it does not necessarily follow that a reversal of any principle is called for. There are counter-balancing factors. For instance, investment bankers may have a very real and substantial interest in the success of a corporation because the good-will of their customers is dependent upon it even though they may not directly own any of its securities. Another factor not yet judicially recognized is that, by and large, the modern stockholder is an investor primarily interested in financial return and not a partner in a business venture interested in controlling its policies. ${ }^{201}$ Older considerations which have not yet exerted appreciable influence on the law are that corporate charters are no longer contracts negotiated between the state and the incorporators ${ }^{202}$ and that the concurrence in the terms of the charter and by-laws imposed on the stockholders is almost always based upon a legal fiction and not upon an intelligent, free consent in fact. ${ }^{203}$

Of course, most of the elements here mentioned apply only to the large "public" corporations and not to "close" corporations. The ever widening gap in practice between the two classes may require the division of corporation law into two branches. ${ }^{204}$ A short step toward this is to recognize the difference between majority control as exercised by a small, compact group, and that exercised by virtue of a majority vote of a large, widely scattered body of stockholders.

Beneath and beyond all these considerations is the ultimate obligation adequately to protect the minority against illegality, fraud and unfairness

${ }^{18 s}$ For a stimulating and suggestive presentation of some of the legal economic factors involved in the present corporate system, see BERLE AND MEANs, THE Modern Corporation and Private Property (1932).

103 Robotham v. Prudential Insurance Co., supra note 31 ; Barnes v. Brown, 80 N. Y. 527, 537 (I880); Thalmann v. Hoffman House, supra note I77; Shaw v. Davis, sutra note 20, at 328-9; Cone v. Russell \& Mason, 48 N. J. Eq. 208, 2r Atl. 847 (I8gr).

000 Because of the use of bonds, non-voting classes of stock, scattered stock ownership, and the use of various devices to keep control regardless of the investment. The writer has in course of preparation an article on perpetuating control.

sin See Kline, sipra note 28.

See Katz v. DeWolf, I5I Wis. $337,344,138$ N. W. IOI3, ror5 (Igr2); Ripin v. U. S. Woven Label Co., 205 N. Y. 442, 447, 98 N. E. 855, 856 (IgI2) ; (I93I) 44 HARv. L. REv. 442 .

${ }^{23}$ As to constructive notice to the public of the contents of certificates of incorporation and by-laws see Stevens, $A$ Proposal as to the Codification and Restatement of the Ultra Vires Doctrine (1927) 36 Yale L. J. 297, 326-327; UNIForar Business CoRPorations ACT, 9 U. L. A. (1932) \& I0.

-4 A distinction between corporations whose stock has a ready market and "close" corporations has been accepted as valid in determining whether dividends are being improperly withheld. See Raynolds v. Diamond Mills Paper Co., 59 N. J. Eq. 299, 309-3I0, 60 At1. 94I, 945 (1905); Hiscock v. Lacy, supra note 30 . See also SperLAIAN, CoRporate Directors (I93I) \$ 9 . 
without encouraging the "striker" or litigious stockholder and without hamstringing honest management. The courts are alert to the problem. ${ }^{205} \mathrm{~A}$ subtle danger to be guarded against from even honest management is the feeling which it frequently has that all other stockholders are only parasites profiting from its labors. ${ }^{206}$ Justified by this psychological attitude it frequently becomes "ingenious in devising methods to evade and avoid [its] corporate responsibilities". ${ }^{207}$ The danger from the minority lies primarily in the comparative ease with which one bent solely upon personal profit may, in the role of minority stockholder, invoke the aid of equity whether or not his action is intended for the best interests of the corporation on whose behalf he is nominally acting. ${ }^{208}$ In most cases, it is likely that a fair result can be reached by the application of proper rules respecting such questions as the plaintiff's interest in the corporation and his motives. ${ }^{200}$ It is suggested that in all cases, except where the plaintiff has an unqualified legal right, if he represents a very small financial interest, the court limit its interference with the majority to assuring to all stockholders of the same class equality of treatment, but, if the opposition represents a substantial interest, (especially if the stock does not have a ready market) the court should review the fairness and wisdom of the action proposed by the majority, allowing the majority, if it be honest and "disinterested", a presumption in favor of its action. ${ }^{210}$ Ordinarily, if there is an active market for the stock, a dissatisfied stockholder would prefer to sell his stock rather than litigate the competence of the majority. Assuming that there has been no dishonesty and the prevailing market is a fair one, this might be deemed sufficient redress. Conversely, it is the existence of a ready market that makes most stockholders in the large corporations disinterested in managerial problems.

sos "In proper cases courts protect minorities, even minorities of one, against the oppression of the majority of stockholders and boards of directors. It sometimes happens, however, that a minority institute 'strike' suits and seek to oppress majorities and to involve the corporation itself in disaster for purposes of their own and for reasons not always revealed. So that there are cases in which courts are compelled to protect minorities against majorities and majorities against minorities." Staats v. Biograph Co., 236 Fed. 454, 457 (C. C. A. 2d, I9I6). note $4 \mathrm{I}$.

Godley v. Crandall \& Godley Co., supra note 44; Dodge v. Ford Motor Co., supra

${ }_{307}^{41}$ Clarke, J. in Godley v. Crandall \& Godley Co., supra note 44. The purpose may at times be wholly praiseworthy. See Dodge v. Ford Motor Co., supra note 4I.

${ }^{200}$ Even if the motive be the entirely proper one of holding corporations strictly to the letter of the law, excessive litigiousness may be an undue burden both upon the courts and the corporations. See Sears, THE NEw Place of THE STockholder (1929) I99, for citations of nineteen cases brought by one Clarence $H$. Venner. The entire problem of reconciling the right to insist upon the letter of the bond and the requirements of good morals is an old one still unsolved. See Graf v. Hope Bldg. Corp., 254 N. Y. I, I7 I N. E. 884 (I930).

${ }^{c 09}$ See text supra, page 7 I7 et seq.

20 Recent experiences in reorganizations, particularly upon real estate mortgage foreclosures, has brought sharply to the fore the need for a tribunal to reconcile differences of opinion between majorities and minorities. See Clinton Trust Co. v. I42-I44 Joralemon Street Corp., decided by the. New York Appellate Division (2d Dept.), Mar. Io, 1933. Arbitration has been turned to. In a recent railroad foreclosure, Central Hanover Bank \& Trust Co. v. Ulster \& Delaware R. R. Co., (S. D. N. Y.) pending before him, Circuit Judge Mack arbitrated some such questions which arose incidentally. 
Similarly, the rules applicable to "motive" ought, perhaps, to be more precisely formulated. Under the present state of the law, the following are submitted:

I. Where the majority, the directors, or the officers, are guilty of illegal acts, $i . e$., of acts which the corporation itself cannot authorize or ratify, the motive of the complaining stockholder is immaterial.

2. Where the minority stockholder is insisting upon the fulfillment of a contract right, whether embodied in the charter, certificate of incorporation, or otherwise, his motive is immaterial. Illustrative of this class are cases of preferred stockholders seeking the payment of dividends.

3. Where the suit involves the propriety of the exercise of a power vested in the majority, the directors, or the officers, the motive of the complaining minority stockholder is material (but not controlling), provided the inquiry is directed towards aiding the court to determine, under all the circumstances, the effect of the litigation upon the corporation and all interested therein, and not to the ascertainment of whether the plaintiff is a "good" or "bad" man. It is submitted that the ultimate welfare of the corporation and of those dependent upon it is a legitimate subject of inquiry and that courts should make the inquiry openly and not under the guise of determining whether the plaintiff is "the real party in interest." 211 written.

min See Tachna v. Pressed Steel Car Co., supra note 177 , decided after this article was 